\title{
Why Do Short Sellers Like Qualitative News?
}

\author{
Bastian von Beschwitz, Oleg Chuprinin, and Massimo Massa*
}

\begin{abstract}
Short sellers trade more on days with qualitative news, that is, news containing fewer numbers. We show that this behavior is not informationally motivated but can be explained by short sellers exploiting higher liquidity on such days. We document that liquidity and noise trading increase in the presence of qualitative news, enabling short sellers to better disguise their informed trades. Natural experiments support our findings. Qualitative news has a bigger effect on short sellers' trading after a decrease in liquidity following the stock's deletion from the Standard \& Poor's 500 index and a smaller effect when investor attention is distracted by the Olympic Games.
\end{abstract}

\section{Introduction}

Does the market react differently to qualitative and quantitative information? We know that "soft" (i.e., more qualitative) information gets transmitted within an organization differently from hard information (e.g., Stein (2002)). However, we know relatively little about the way financial markets react to the type of information. In this article, we investigate this issue by studying the reaction of short sellers to qualitative news releases. We focus on short sellers because prior research depicts them as informed/sophisticated investors (Cohen, Diether, and Malloy (2007), Boehmer, Jones, and Zhang (2008), and Engelberg, Reed, and Ringgenberg (2012)) and informed investors should be less influenced by media. The focus on short sellers is also of particular interest given the recent debate on their role in financial markets: Although politicians and the public often view short selling as a destabilizing factor, financial research regards short sellers as informed participants who maintain market quality and improve price efficiency.

*von Beschwitz (corresponding author), bastian.vonbeschwitz@gmail.com, Federal Reserve Board, International Finance Division; Chuprinin, o.chuprinin@unsw.edu.au, School of Banking and Finance, University of New South Wales; and Massa, massimo.massa@insead.edu, INSEAD Finance Department. We thank the UniCredit \& Universities Knight of Labor Ugo Foscolo Foundation for a research grant that made this study possible. We have benefited from feedback provided by Paul Malatesta (the editor), Ingrid Werner (the referee), and seminar participants at INSEAD. A prior version of this paper was titled "Trading on Fluffy News: The Effect of Information Tangibility on Short Sellers' Behavior." 
We use media coverage of firm-specific news and separate it into tangible (or quantitative) and intangible coverage. Tangibility is measured as the percentage of numbers relative to words across all media articles about a company on a given day. Intuitively, whereas quantitative news is easier to interpret in terms of market expectations, intangible news admits more ambiguous interpretation. For example, earnings announcements that (quantitatively) fall short of expectations unambiguously provide a bad signal and depress the stock price, whereas an article that describes a firm's strategy verbally can be interpreted differently by optimists and pessimists.

Our analysis uses a comprehensive data set on equity lending provided by DataExplorers (now Markit). This data set has been used in finance studies (e.g., Saffi and Sigurdsson (2011)) and has become the main source of information on short selling. The data allow us to measure daily short-selling activity at the stock level from July 2006 to Dec. 2008. Importantly, we can observe both the newly initiated short positions and the closing of existing short positions. Exploiting this data feature, we construct a nondirectional measure of short sellers' trading activity that can be compared to the overall trading volume in the stock and is well suited to study the effects of media coverage on short-sale trading. In addition, we collect media coverage data from Factiva for all public U.S.-based companies that ranked in the top 1,000 by market capitalization at any time between Jan. 1999 and Dec. 2008. We define our measure of information intangibility for each companyday pair as 1 minus the percentage of numbers across all articles featuring the company in major news and business publication, newswires, and press releases on the day of the observation.

We investigate whether short sellers react differently to news depending on its tangibility. We consider days with company news coverage ("news days") and find that short sellers' trading activity is significantly greater on news days dominated by intangible information. After controlling for an array of stock characteristics, we find that the ratio of short sellers' trading to the overall trading volume in the stock increases by $5 \%$ relative to its median on days with above-median information intangibility. This result is significant at the $1 \%$ level and is robust to alternative definitions of short sellers' trading activity and to various subsamples. Interestingly, both the initiations of new short positions and the closings of old positions increase on intangible news days. This finding suggests that short sellers condition their trading behavior on the company's information environment.

How do we explain the surprising result that apparently sophisticated investors react more strongly to qualitative news? We consider two alternative hypotheses. The first is the information hypothesis. It posits that short sellers are better able to interpret intangible information. This intuition is in line with the recent findings by Engelberg et al. (2012), who show that short sellers possess superior information-processing skills that allow them to decode valuable information from public news announcements. ${ }^{1}$ If this skill is more pronounced for intangible news, this would explain our result. The second hypothesis is the liquidity

\footnotetext{
${ }^{1}$ We replicate this study within our sample and find consistent results (see Internet Appendix IA.3, available at www.jfqa.org), confirming the overall ability of short sellers to better decode valuable information transmitted through public news.
} 
hypothesis. It posits that intangible news releases attract more noise trading, thereby increasing liquidity. Short sellers can then exploit this liquidity to post their informed trades, as in Kyle (1985). To summarize, we ask whether active trading of short sellers on intangible news days is driven by improved liquidity conditions on such days (liquidity hypothesis) or by short sellers' ability to extract valuable information from intangible news (information hypothesis).

We first test whether short sellers derive a greater information advantage from intangible news, as predicted by the information hypothesis. If this were the case, their trades on intangible news days would be more profitable and predict future returns better (Engelberg et al. (2012)). Alternatively, increased liquidity on intangible news days should not affect the predictive power of the trades. We find that although shorting on news days is profitable on average, this profitability is not higher on days with intangible news. This finding fails to support the information hypothesis, suggesting that short sellers do not draw unique and valuable information signals from intangible news.

We now switch to the liquidity hypothesis. We document that liquidity and noise trading increase on days with qualitative news. We consider two tests. The first test shows that intangible news induces noise trading and stimulates stock liquidity as described in Kyle (1985). Specifically, we follow Campbell, Grossman, and Wang (1993), Llorente, Michaely, Saar, and Wang (2002), and Tetlock (2010) and use mean reversion in stock returns as a measure of noise trading. We show that returns tend to mean revert more strongly following intangible news days. On average, in the 10 days following the news day about $5 \%$ of the original event-day return is eliminated. This effect increases to about $8 \%$ as the fraction of nonnumeric words in the article goes up by 1 standard deviation. In line with the liquidity hypothesis, this evidence suggests that less fundamental information is incorporated into the stock price on days with intangible media releases.

Our second test of the liquidity hypothesis focuses on the link between the intangibility of media articles about a company and the liquidity of the company's stock. We show that liquidity increases in the presence of intangible news. This result is statistically and economically significant. Amihud (2002) illiquidity goes down by around $21 \%$ relative to the median when the fraction of nonnumerical words in a news article increases by 5 percentage points (about 1 standard deviation). This finding suggests that intangible information results in more noise trading, either by increasing the dispersion of opinion in the market or by attracting additional attention to the stock.

We provide further evidence of the liquidity hypothesis using two natural experiments. First, we use the Olympic Games as an exogenous shock to attention. Although the Olympic Games have very limited effects on the real economy, they are a large distraction for attention-motivated noise traders. Indeed, our results indicate that the effect of news intangibility on liquidity completely disappears during the Olympic Games, consistent with the idea that attention-driven trading is less prevalent at such times. Confirming the liquidity hypothesis further, we also find that short sellers do not react to information intangibility during the Olympic Games. 
The second experiment is linked to exogenous shifts in stock liquidity. If the stronger reaction of short sellers to qualitative news is driven by liquidity, we would expect short sellers to react less to intangible news for stocks that are already more liquid for some institutional reason. We focus on the exogenous increase in liquidity associated with the addition of a stock to the Standard \& Poor's (S\&P) 500 index. We find that short sellers' trading is less sensitive to news intangibility after a stock is added to the S\&P 500 index, further confirming that liquidity plays a key role in determining short sellers' reactions to intangible news.

Overall, our findings are consistent with the (liquidity) hypothesis that short sellers rely on the overall increase in trading activity at times of investor disagreement to better disguise their bets. In other words, because the presence of noise traders reduces the market impact of short sellers' orders, short sellers prefer to execute their trades on days characterized by lower news tangibility, as suggested by the theoretical arguments in information economics (e.g., Kyle (1985), Admati and Pfleiderer (1988)).

It is important to note that we are not investigating the causal effect of different media channels on investor behavior, as done, for example, in Engelberg and Parsons (2011), Dougal, Engelberg, Garcia, and Parsons (2012), and von Beschwitz, Keim, and Massa (2016). Instead, we acknowledge that the underlying corporate events trigger the stock market reaction rather than a particular coverage of these events by the media. We simply analyze the parameters of media articles to understand the nature of the events and the type of information associated with them.

Our findings contribute to different strands of the finance literature. First, we add to the literature on short selling and liquidity. Several studies show that short sellers increase liquidity and market efficiency (Bris, Goetzmann, and Zhu (2007), Boehmer, Jones, and Zhang (2013), Boehmer and Wu (2013), Saffi and Sigurdsson (2011), and Beber and Pagano (2013)). We add to this literature by showing that there exists an effect in the opposite direction: Short sellers tend to exploit excess liquidity created by noise traders to place their trades. Overall, our findings are consistent with studies showing that hedge funds are net users rather than providers of liquidity (e.g., Ben-David, Franzoni, and Moussawi (2012), Cao, Chen, Liang, and Lo (2013)).

Second, we contribute to the literature on short selling and information. Several papers show that short sellers' trading activity predicts future stock returns (e.g., Boehmer et al. (2008), Engelberg et al. (2012), Cohen et al. (2007), and Diether, Lee, and Werner (2009)). This result suggests either that short sellers have access to private information or that they are able to use publicly available information more efficiently. The latter view is supported by the recent paper by Engelberg et al. (2012), which attributes short sellers' trading activity and success to their superior information interpretation skills. We refine this argument by showing that this mechanism holds largely for news with little ambiguity (i.e., quantitative news). In contrast, for qualitative news, a different mechanism is in operation: the strategic use of liquidity to avoid the adverse selection discount.

Third, our findings contribute to the literature on financial media. This literature has largely focused on the effect of media on the cost of capital (Fang 
and Peress (2009)), information asymmetry (Tetlock (2010), Bushee, Core, Guay, and Hamm (2010)), and distortions to stock valuations (Tetlock (2007), Tetlock (2011), Tetlock, Saar-Tsechansky, and Macskassy (2008), and Dougal et al. (2012)). Fewer papers examine the difference in the type of news. A recent paper by Boudoukh, Feldman, Kogan, and Richardson (2015) shows that only a subsection of news affects stock returns. Although less impactful itself, unimportant news might still increase attention to a stock and improve liquidity. In general, little is known about how different types of information are linked to liquidity and, more specifically, how different classes of investors use media events. In this article, we bring together these research agendas. Ours is the first study to establish the effect of the type of news on the behavior of short sellers, the sophisticated class of investors, who are likely to differ in their trading decisions from the rest of the market.

Accordingly, we add to the literature on the strategic behavior of informed investors. A number of theoretical (e.g., Grinblatt and Ross (1985), Hirshleifer, Subrahmanyam, and Titman (1994)) and empirical (e.g., Chakravarty (2001), Griffin, Harris, and Topaloglu (2003)) studies emphasize informed investors' ability to take advantage of uninformed traders. We contribute to this literature by showing how qualitative information amplifies uninformed trading, thus allowing informed investors to place their trades at lower costs.

Our study is related to two novel papers. Comerton-Forde, Jones, and Putnins (2016) examine the different properties of short sales depending on whether short sellers place limit or market orders. Collin-Dufresne and Fos (2015) show that when active investors accumulate positions, measures of adverse selection and liquidity are both high. However, these papers sidestep the issue of separating short-selling activity from overall trading and do not conduct any analysis based on news or other exogenous sources of liquidity. In our article, we show how a particular type of public news can be an observable source of liquidity, consistent with the behavioral arguments on attention effects of media, as in Barber and Odean (2008) and Tetlock (2011).

\section{Data and Main Variables}

We mainly use two data sets: Equity lending data provided by DataExplorers (now Markit) and media coverage data extracted from Factiva. In addition, we retrieve data on stock returns, trading volume, balance sheet items, analyst coverage, and institutional ownership from conventionally used databases, as described later.

\section{A. Equity Lending Data}

We obtain equity lending data from DataExplorers, a privately owned company that supplies financial benchmarking information to the securities lending industry and short-side intelligence to the investment management community. DataExplorers collects information from custodians and prime brokers that lend and borrow securities and is the leading provider of securities lending data. Although DataExplorers supplies international data for bonds as well as equity, we limit our attention to the 1,581 largest American stocks that are covered in our 
media sample. The data are available at a daily frequency from July 2006 to Dec. 2008. For each stock, DataExplorers reports the following variables at daily frequency: Lendable value in dollars, active lendable value in dollars, total balance value on loan in dollars, and weighted average loan fee (across active contracts) in basis points.

The main reason for borrowing equity is short selling. To keep their positions open overnight, short sellers must borrow the stock from its owner. Thus, the level of equity on a loan serves as a good approximation of short-selling interest. Equity lending data have been used to study short selling in numerous studies, including Geczy, Musto, and Reed (2002) and Saffi and Sigurdsson (2011).

In the United States, equity transactions are settled after 3 trading days, whereas equity loans are settled immediately. Accordingly, a short seller does not need to borrow a stock until 3 days after taking the short position. Therefore, following Geczy et al. (2002) and Thornock (2013), we compute the amount of stock shorted on day $t$ using equity lending information from day $t+3$. We illustrate the difference between the shorting and the lending dates in Figure 1, which displays total turnover and equity lending around important news events when a company is mentioned in more than three articles. Although the trading volume spikes on the news day, equity lending peaks exactly 3 days later. In Graph B and the remainder of this article, we compute shorting using the newly borrowed shares on day $t+3$. After this time adjustment, the peaks in trading volume and short selling coincide, validating the adjustment.

The DataExplorers data set is important in that it contains information on the number of shares that are on loan as well as the number of shares that have been lent out during the day. ${ }^{2}$ This feature of the data allows us to compute the number of shares returned to lenders during the day as follows: ${ }^{3}$

\section{SHARES_RETURNED $_{t}=$ SHARES_NEWLY_BORROWED $_{t}$ - SHARES_ON_LOAN ${ }_{t}+$ SHARES_ON_LOAN ${ }_{t-1}$.}

We call the number of shares newly lent out at $t+3$ divided by the number of shares outstanding SHORTING and the number of shares returned to lenders at $t+3$ divided by the number of shares outstanding CLOSING. We define SHORT-SALE_TURNOVER as the sum of these two variables. Importantly, unlike some variables in the literature that have been dubbed "short sale trading volume," this measure has the unique feature of being nondirectional, as it incorporates short selling as well as buying of a stock to cover a short position. Therefore, this variable can be naturally compared to the overall trading volume in the market.

We calculate several proxies of short sellers' trading activity. Our main proxy is the relative short-sale turnover (REL_SHORT-SALE_TURNOVER), defined as the ratio of SHORT-SALE_TURNOVER to TOTAL_TURNOVER, where

\footnotetext{
${ }^{2}$ These numbers are obtained by dividing the value of stocks on loan (Total Balance Value) and the value of stocks lent out during the latest day (Balance Value 1 Day) by the closing price of the stock on the day.

${ }^{3}$ Because of some minor data inconsistencies, this variable can be negative in a small number of cases. In such cases, we set it equal to 0 .
} 


\section{FIGURE 1}

\section{3-Day Lag between Shorting and Stock Lending}

Figure 1 shows stock lending and trading activity around news days with more than three articles covering a single company. In Graph A, we display the mean of Total Turnover (Trading Volume/Shares Outstanding) and the mean of Equity Lending (Newly Borrowed Stocks/Shares Outstanding) around a news event. Total Turnover is displayed with respect to the left $y$-axis. Equity Lending is displayed with respect to the right $y$-axis. The $x$-axis displays the days relative to the news event. In Graph B, we shift the lending data by 3 days to match the date the stock was most probably shorted.

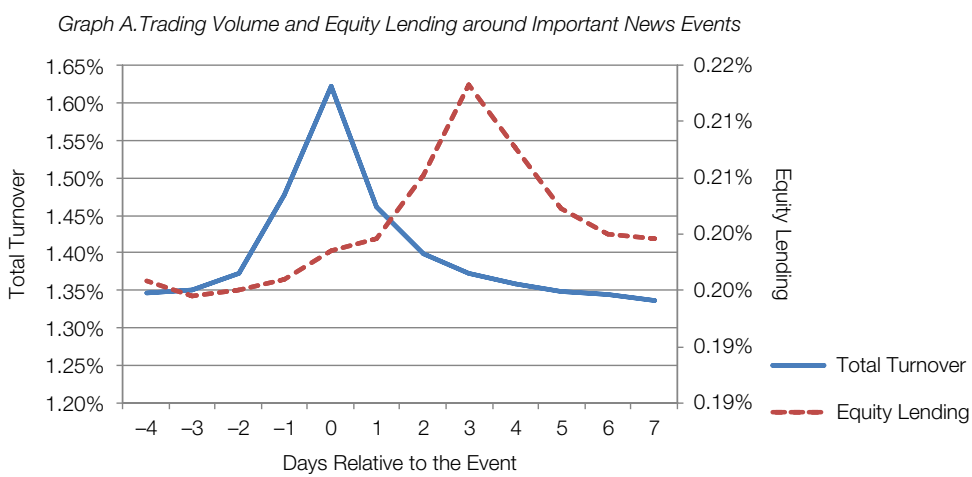

Graph B. Trading Volume and Short Selling (Equity Lending Shifted by 3 Days) around Important News Events

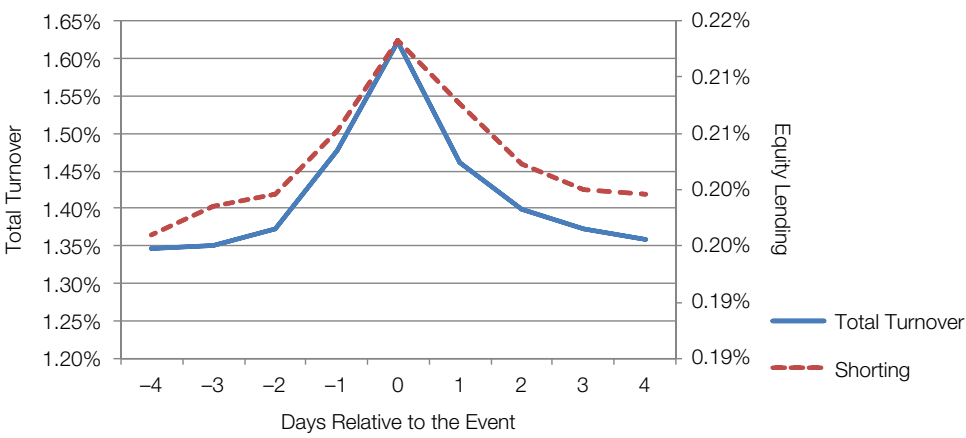

TOTAL_TURNOVER is the ratio of share trading volume to the number of shares outstanding. ${ }^{4}$ We also consider REL_SHORTING and REL_CLOSING, whereby we divide our SHORTING and CLOSING variables by total turnover. As a robustness check, we calculate two alternative measures of short-selling activity: Abnormal relative short-sale turnover (ABN_REL_SHORT-SALE_TURNOVER) as the natural logarithm of the ratio of REL_SHORT-SALE_TURNOVER on the day to its average value over the trailing 125 trading days, and the difference in abnormal turnover (DIFF_IN_ABN_TURNOVER) as the difference between ABN_SHORT-SALE_TURNOVER and ABN_TOTAL_TURNOVER. These variables allow us to detect unusual spikes in short-selling activity relative to its longrun average level.

\footnotetext{
${ }^{4}$ Because of minor data inconsistencies, this variable can be above 2 in a small number of cases ( 2 is the maximum possible logical value for this variable; it occurs when all buy and sell orders in the market are placed by short sellers). In such cases, we set it equal to 2 .
} 


\section{B. Media Data}

We obtain media data from Factiva, a subsidiary of Dow Jones \& Company that collects data from over 28,000 news sources worldwide. We collect the data for any U.S. company that ranked in the top 1,000 by market capitalization at any time between 1999 and 2008. For each of the 1,581 companies that fit this definition, we obtain a Factiva intelligent indexing code by searching for the company name in Factiva. Codes are assigned by Factiva to assist researchers in finding articles that mention a specific company in a meaningful context. Wherever the code assignment is ambiguous (e.g., where different codes identify the same company over different periods), we analyze several articles returned by the Factiva engine to determine the proper correspondence. We eliminate company-years for which the link from Factiva to the Center for Research in Security Prices (CRSP) cannot be reliably established.

For each Factiva code, we download all articles that are categorized under "Major News and Business Publications," "Press-Release Wires," or "Reuters Newswires." We limit our search to all articles in the English language appearing between Jan. 1999 and Dec. 2008. In addition to the text of the article, we are able to obtain information about the exact date and time of publication (where indicated), the author of the piece (if applicable), the number of words in the article, the name of the source (e.g., The Wall Street Journal), and the title. After the download, we eliminate duplicate articles. We further eliminate articles that contain empty bodies, where the number of words is 20 or fewer, and where the quantity of numbers is more than one-third. Because we are interested in the market reaction to the information contained in the news, we reassign dates in such a way that all articles appearing after the market closure correspond to the next trading day.

Our main variable of interest is the type of information contained in media publications. Specifically, we want to distinguish between news items that are more qualitative and that are subject to differential interpretation and news items that are more quantitative and therefore less likely to cause disagreement among investors. We define a measure of information intangibility (INF_INTANG) as follows. First, for each article, we calculate 1 minus the ratio of numbers to total words in the article. The resulting measure is low for articles that report a lot of numbers and is high for news that contains mostly verbal content. Next, we average this measure across all of the articles about a company on a given day. Finally, we subtract the median of this measure calculated across all companydays in the observation year. Subtracting the median does not change the results of our main regressions but does allow us to interpret constituent coefficients in regressions with interaction effects. The INF_INTANG variable is defined only for days in which an article about the company appears in the news. In other words, our analysis does not focus on the news coverage itself, but on the type of news. ${ }^{5}$

In alternative specifications, we also consider INF_INTANG_DUMMY, which equals 1 for positive INF_INTANG, and 0 otherwise. In addition, we check

\footnotetext{
${ }^{5}$ In Internet Appendix IA.1, we describe the procedure of analyzing Factiva articles for numbers. In Internet Appendix IA.2, we provide examples of articles with distinct intangibility scores. These details are important for validation and replication of our methodology.
} 
the robustness of our results using ABN_INF_INTANG, defined as the natural logarithm of 1 minus the average fraction of numbers in all company-related articles on the day divided by its mean over the past 125 trading days. This variable is set to missing if there are fewer than 5 news days within the last 125 trading days.

As a control variable, we construct the sentiment of each article (following the methodology in Tetlock (2007) and Loughran and McDonald (2011)) by dividing the number of negative words by the total number of words. The list of negative words is provided by Loughran and McDonald (2011).

\section{Other Variables}

For our sample of firms, we retrieve stock market data from CRSP and balance sheet data and S\&P 500 constituency data from Compustat. In addition, we use the Institutional Brokers' Estimate System (IBES) database to construct measures of analyst following and dispersion. We define NUMBER_OF_ANALYSTS as the natural logarithm of 1 plus the number of analysts that issued earnings forecasts for the stock in the observation period. We compute ANALYST_DISPERSION as the standard deviation of the analysts' earnings forecasts scaled by the stock price at the beginning of the quarter. This variable is set to missing if the stock is covered by fewer than three analysts. We obtain data on institutional ownership from Thomson Reuters $13 \mathrm{~F}$ filings. INST_OWNERSHIP is computed as the aggregate number of shares held by institutional investors divided by the total number of shares outstanding. BREADTH_OF_OWNERSHIP is defined as the number of institutions holding the stock divided by the number of all reporting institutions in the period (similar to the definition used in Chen, Hong, and Stein (2002)).

As a measure of liquidity, we compute AMIHUD_ILLIQUIDITY using daily data from CRSP as $\ln \left(1+10^{6} \times \mid\right.$ RETURN|/(DOLLAR_VOLUME) $) .{ }^{6}$ We also consider the bid-ask spread. However, because the closing bid-ask spreads on CRSP are often driven by idiosyncrasies at the end of the trading day, we obtain intraday trading and quotes data from New York Stock Exchange (NYSE) Trade and Quote (TAQ). We split the trading day into seventy-eight 5-minute intervals and calculate the bid-ask spread at the end of each 5-minute interval as (ASK_PRICE - BID_PRICE)/(0.5 × ASK_PRICE + $0.5 \times$ BID_PRICE) using the last quote of the 5-minute interval. Then we take an equal-weighted average of the results to construct our bid-ask spread measure at daily frequency.

In a further robustness check, we use TAQ data to compute INTRADAY_AMIHUD_ILLIQUIDITY as $\ln \left(1+10^{6} \times\right.$ mean $_{\text {over_5-min_intervals }}\left(\left|\mathrm{RETURN}_{\tau}\right| /\right.$ DOLLAR_VOLUME $\left._{\tau}\right)$ ). To mitigate the effect of outliers, we winsorize all our continuous variables at the top and the bottom $1 \%$.

\section{Summary Statistics}

Our short-selling data span July 2006 to Dec. 2008, and the media data span Jan. 1999 to Dec. 2008. Accordingly, for analyses that require media data only we use the whole 10-year period, whereas for analyses directly related to short

\footnotetext{
${ }^{6}$ In some tables, we scale up this variable by $10^{3}$ to facilitate the interpretation of coefficients.
} 
selling we use the 2006-2008 period. In all of our analyses, we limit our attention to days with news coverage.

In Panel A of Table 1, we report summary statistics for the 1,581 companies for which we have media data. Our sample consists of fairly big firms with an average market capitalization of $\$ 12.5$ billion (median of $\$ 3.8$ billion). The mean (median) number of analysts following the stock is 13 (12) and around $70 \%$ of shares are held by institutional investors; $40 \%$ of our companies are constituents

TABLE 1

\title{
Summary Statistics
}

\begin{abstract}
In Panel A of Table 1, we list company-specific variables for the 1,581 companies in our sample. MARKET_CAP is the company's market capitalization in millions of dollars. MARKET-TO-BOOK is equal to the company's market capitalization divided by the book value of equity. BREADTH_OF_OWNERSHIP is the number of institutions holding the stock divided by the total number of institutions that report holdings. NUMBER_OF_ANALYSTS is the number of analysts on the Institutional Brokers' Estimate System (IBES) who issued an earnings forecast for the stock. ANALYST_DISPERSION is the standard deviation of analysts' earnings forecasts on IBES scaled by the stock price. INST_OWNERSHIP is the percentage of shares outstanding held by institutions. S\&P_500_DUMMY is an indicator variable equal to 1 if a company is an S\&P 500 constituent. In Panel B, we list summary statistics for the 929,181 company-days with news between Jan. 1999 and Dec. 2008. NUMBER_OF_NUMBERS is the percentage of numerical words in the articles about the company on the day. NUMBER_OF_ARTICLES is the natural logarithm of 1 plus the number of articles about the company on the day. INF_INTANG is defined as 1 minus the average percentage of numbers in all the articles covering the company on the day (less 1 minus the median of the percentage of numbers in all articles in the year). NEGATIVE_WORDS is the average percentage of negative words in all articles for the company on the day. Daily AMIHUD_ILLIQUIDITY is defined as $\ln \left(1+10^{6} \times\right.$ RETURN//(DOLLAR_VOLUME)) and INTRADAY_AMIHUD_ ILLIQUIDITY is defined as $\ln \left(1+10^{6} \times\right.$ mean $_{\text {over_5-min_nntervals }}\left(\mid R_{\text {RETURN }} / /\right.$ DOLLAR_VOLUME $\left.\left._{\tau}\right)\right)$. BID-ASK_SPREAD is defined as mean over.5-min_intervals $_{(}($ASK $\left.-\mathrm{BID}) /(0.5 \times \mathrm{ASK}+0.5 \times \mathrm{BID})\right)$. ABSOLUTE_RETURN is the absolute value of the stock's daily return. In Panel C, we list summary statistics for the short-selling variables for the 263,232 company-days with news between July 2006 and Dec. 2008. LOANED_SHARES is the number of shares on loan divided by the shares outstanding. SHORTING (CLOSING) is the number of shares borrowed from (returned to) lenders on the day divided by the shares outstanding. SHORT-SALE_TURNOVER is the sum of borrowed and returned shares divided by the shares outstanding. TOTAL_TURNOVER is the number of shares traded divided by the shares outstanding. REL_SHORTING (REL_CLOSING) is SHORTING (CLOSING) divided by TOTAL_TURNOVER. REL SHORT-SALE_TURNOVER is the sum of REL_SHORTING and REL_CLOSING. ABN_REL_SHORT-SALE_TURNOVER is the natural logarithm of REL_SHORT-SALE_TURNOVER scaled by its 125-day mean. DIFF_IN_ABN_TURNOVER is the difference between ABN_SHORT-SALE_TURNOVER and ABN_TOTAL_TURNOVER (both variables are defined as the respective natural logarithms of the today's value divided by the corresponding past 125-day average).
\end{abstract}

\begin{tabular}{|c|c|c|c|c|c|}
\hline Variables & Median & Mean & P25 & P75 & Std. De \\
\hline \multicolumn{6}{|l|}{ Panel A. Company Variables } \\
\hline MARKET_CAP (\$millions) & 3,797 & 12,532 & 2,049 & 9,904 & 28,459 \\
\hline MARKET-TO-BOOK & 2.68 & 3.88 & 1.76 & 4.43 & 3.76 \\
\hline BREADTH_OF_OWNERSHIP (\%) & 10.53 & 13.53 & 7.47 & 15.99 & 9.77 \\
\hline NUMBER_OF_ANALYSTS & 12 & 13 & 8 & 17 & 7.1 \\
\hline ANALYST_DISPERSION (\%) & 0.11 & 0.25 & 0.05 & 0.25 & 0.45 \\
\hline INST_OWNĒERSHIP (\%) & 72.8 & 69.2 & 57.5 & 84.5 & 19.8 \\
\hline S\&P_500_DUMMY & 0 & 0.40 & 0 & 1 & 0.49 \\
\hline
\end{tabular}

$\underline{\text { Panel B. Media Coverage and Liquidity Variables (large sample) }}$

\begin{tabular}{|c|c|c|c|c|c|}
\hline NUMBER_OF_NUMBERS (\%) & 4.7 & 6.0 & 3.1 & 7.4 & 4.6 \\
\hline NUMBER_OF_ARTICLES & 2 & 4 & 1 & 4 & 6.6 \\
\hline INF_INTANG & 0.0 & -0.012 & -0.026 & 0.016 & 0.045 \\
\hline NEGATIVE_WORDS (\%) & 0.80 & 1.04 & 0.33 & 1.46 & 1.02 \\
\hline AMIHUD_ILLIQUIDITY & 0.00019 & 0.00068 & 0.000056 & 0.00061 & 0.0014 \\
\hline INTRADAY_AMIHUD_ILLIQUIDITY & 0.0030 & 0.014 & 0.00099 & 0.010 & 0.032 \\
\hline BID-ASK_SPREAD & 0.0032 & 0.0044 & 0.0016 & 0.0056 & 0.0042 \\
\hline ABSOLUTE_RETURN (\%) & 1.26 & 1.97 & 0.55 & 2.57 & 2.11 \\
\hline \multicolumn{6}{|c|}{ Panel C. Short-Selling Variables (small sample) } \\
\hline LOANED_SHARES (\%) & 2.66 & 5.15 & 1.01 & 7.05 & 6.00 \\
\hline SHORTING (\%) & 0.11 & 0.23 & 0.03 & 0.28 & 0.33 \\
\hline CLOSING (\%) & 0.10 & 0.26 & 0.02 & 0.30 & 0.41 \\
\hline SHORT-SALE_TURNOVER (\%) & 0.24 & 0.49 & 0.09 & 0.60 & 0.66 \\
\hline TOTAL_TURNOVER (\%) & 0.96 & 1.41 & 0.56 & 1.70 & 1.38 \\
\hline REL_SHORTING (\%) & 10.34 & 19.79 & 3.87 & 23.13 & 28.17 \\
\hline REL_CLOSING (\%) & 10.43 & 22.54 & 2.31 & 27.15 & 34.26 \\
\hline REL_SHORT-SALE_TURNOVER (\%) & 23.87 & 40.42 & 10.55 & 50.81 & 46.01 \\
\hline ABN_REL_SHORT-SALE_TURNOVER & -0.35 & -0.45 & -1.04 & 0.27 & 1.05 \\
\hline DIFF_IN_ABN_TURNOVER & -0.09 & -0.15 & -0.92 & 0.69 & 1.24 \\
\hline
\end{tabular}


of the S\&P 500 Index. In Panel B, we report summary statistics on the media variables for the full sample of 929,181 company news days. Conditional on there being an article on a given day, the average (median) number of articles is 4 (2). On average (median), $6.0 \%$ of the words in an article are numbers $(4.7 \%)$. About $1 \%$ of the words in an article are negative words, as defined by Loughran and McDonald (2011), similar to the fraction they observe in 10-K documents.

In Panel C of Table 1, we report summary statistics for the short-selling variables based on the 263,232 company news days of the smaller sample, for which we have short-selling data. On average, $5.15 \%$ (median $2.66 \%$ ) of shares outstanding are on loan at any given time, and $0.23 \%$ (median $0.11 \%$ ) are newly shorted on any given day. The average (median) short-sale turnover is $0.49 \%(0.24 \%)$. This constitutes roughly one-third of the total turnover in the market, which has a mean of $1.41 \%$ and a median of $0.96 \%$. These numbers are consistent with those reported by Diether et al. (2009), who estimate that $24 \%$ of all trades on the NYSE and $31 \%$ of all trades on NASDAQ are short-sale transactions.

\section{News Intangibility and Short Sellers' Trading}

We start by relating the effect of news intangibility to short-selling activity. In Figure 2, we display an event-study analysis around days with company news releases. We classify the news days characterized by information intangibility in the top 30\% (bottom 30\%) as "intangible news days" ("quantitative news days"). This figure shows the difference in short-sale turnover between these two sets of days around the news event. Graph A illustrates the difference in mean, and Graph $\mathrm{B}$ illustrates the difference in median. Although the difference is close to zero 2 days after the news release, all three measures of short sellers' trading activity peak on the day the intangible information is released. This result suggests that short sellers are more likely to engage in trading when information about the company is more qualitative.

Next, we examine whether this result carries over to a panel regression specification where the dependent variable is a measure of short-sale turnover. For the baseline specifications, we consider three measures: REL SHORT-SALE_TURNOVER, REL_SHORTING, and REL_CLOSING. The main explanatory variable of interest is INF_INTANG_DUMMY, which equals 1 if the ratio of numbers to words in the article is below the median, and 0 otherwise. The control variables include (for each firm): size, market-to-book ratio, institutional ownership, breadth of ownership, number of analyst forecasts, analyst dispersion, and stock returns of the previous 2 trading days. The number of analysts and their forecast dispersion control for the availability of public information about the company. Breadth of ownership, institutional ownership, and size proxy for the attention the firm receives in the financial market. Trailing stock returns control for short sellers' tendency to act as contrarians (Diether et al. (2009)). We also include the number of articles to control for the pure attention effect due to higher press coverage and additionally to control for the sentiment of the article. In the first specification, we employ firm fixed effects and quarterly fixed effects. In the second specification, we replace quarterly fixed effects with daily fixed effects. 
FIGURE 2

Information Intangibility of News: Event Study

Figure 2 shows short-selling activity around news events. We sort company-days by information intangibility and call the top $30 \%$ of the sample "intangible information" and the bottom 30\% "tangible information." In Graph A (Graph B), we display the difference between the means (medians) of these subsamples for different short-selling measures. The $x$-axis displays the days relative to the news event.

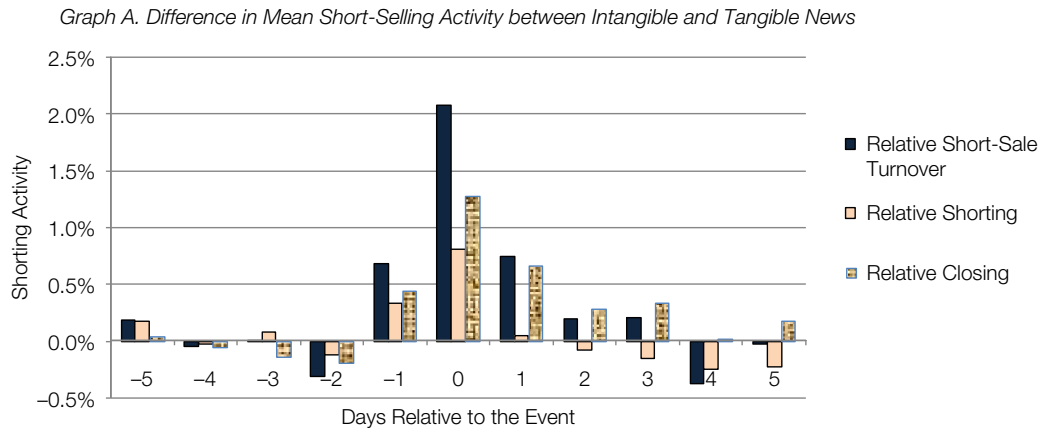

Graph B. Difference in Median Short-Selling Activity between Intangible and Tangible News

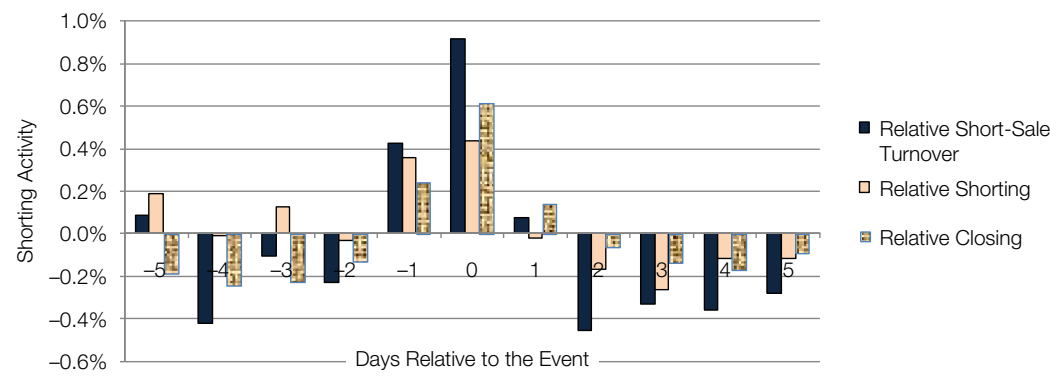

In all regressions, we double-cluster the standard errors at the firm and date levels. The sample period spans July 2006 to Dec. 2008.

We report our findings in Table 2. The main regression specification in Panel A indicates a strong positive relation between news intangibility and all measures of short sellers' trading activity across multiple econometric specifications. The economic effect is also sizable. On days with above-median information intangibility, REL_SHORT-SALE_TURNOVER is higher by $1.20 \%$, or $5 \%$ relative to its unconditional median. The effect is significant for both REL_SHORTING and REL_CLOSING.

We also consider multiple alternative specifications and report the results in Table IA. 1 of the Internet Appendix. For example, we control for the contemporaneous return of the stock on the observation day to account for the direction of the news, and we obtain similar results. We examine the effect of abnormal information intangibility, that is, information intangibility standardized with respect to the prior 125 trading days, and the evidence remains significant. We also show that our results are robust to using the continuous version of information intangibility instead of its dummy variant. Finally, we consider different subsamples based on the type of media sources. Specifically, before we construct INF_INTANG 
TABLE 2

Short Selling as a Function of Information Intangibility

Table 2 reports the results from daily panel regressions that examine the effect of information intangibility on short-selling activity. Dependent variables are REL_SHORT-SALE_TURNOVER, REL_SHORTING, and REL_CLOSING, defined as in Table 1. The explanatory variable of interest is INF_INTANG_DUMMY, which equals 1 if INF_INTANG is above the yearly median, and 0 otherwise. INF INTANG is defined as 1 minus the average percentage of numbers over all the articles covering the company on the day. In Panel A, we perform the analysis on the entire sample. In Panel B, we reestimate the regression using INF_INTANG calculated after the exclusion of articles containing the words "volume," "turnover," or "return." SIZE is the natural logarithm of the stock's market capitalization, RETURN is the daily stock return, and ARTICLE_SENTIMENT is the average of minus the ratio of the number of negative words to the total number of words over all the articles covering the company on the day. The other control variables are defined as in Table 1 . All standard errors are double-clustered at the firm and date levels. The $t$-statistics are reported in parentheses. ${ }^{*}$, **, and ${ }^{* * *}$ indicate significance at the $10 \%, 5 \%$, and $1 \%$ levels, respectively. The sample for this regression consists of news days from July 2006 to Dec. 2008 (excluding the time of the short-sale ban from Sept. 19, 2008 to Oct. 8, 2008).

\begin{tabular}{|c|c|c|c|c|c|c|}
\hline \multirow[b]{3}{*}{ Independent Variables } & \multicolumn{6}{|c|}{ Dependent Variables } \\
\hline & \multicolumn{2}{|c|}{$\begin{array}{c}\text { REL_SHORT-SALE_ } \\
\text { TURNOVER }\end{array}$} & \multicolumn{2}{|c|}{$\begin{array}{l}\text { REL__- } \\
\text { SHORTING }\end{array}$} & \multicolumn{2}{|c|}{$\begin{array}{l}\text { REL_- } \\
\text { CLOSING }\end{array}$} \\
\hline & 1 & 2 & 3 & 4 & 5 & 6 \\
\hline \multicolumn{7}{|l|}{ Panel A. Entire Sample } \\
\hline INF_INTANG_DUMMY & $\begin{array}{l}0.0120^{\star \star \star} \\
(4.88)\end{array}$ & $\begin{array}{l}0.0095^{\star \star \star} \\
(4.25)\end{array}$ & $\begin{array}{l}0.0036^{\star *} \\
(2.53)\end{array}$ & $\begin{array}{l}0.0026^{\star \star} \\
(1.96)\end{array}$ & $\begin{array}{l}0.0089^{* * \star} \\
(5.16)\end{array}$ & $\begin{array}{l}0.0072^{\star \star \star} \\
(4.71)\end{array}$ \\
\hline SIZE & $\begin{array}{l}-0.0774^{\star \star \star} \\
(-4.90)\end{array}$ & $\begin{array}{l}-0.0779^{\star \star \star} \\
(-4.91)\end{array}$ & $\begin{array}{l}-0.0367^{\star \star *} \\
(-4.34)\end{array}$ & $\begin{array}{l}-0.0367^{\star \star \star} \\
(-4.34)\end{array}$ & $\begin{array}{l}-0.0429^{\star \star \star} \\
(-4.44)\end{array}$ & $\begin{array}{l}-0.0435^{\star \star \star} \\
(-4.48)\end{array}$ \\
\hline MARKET-TO-BOOK & $\begin{array}{l}0.0019 \\
(0.58)\end{array}$ & $\begin{array}{l}0.0019 \\
(0.60)\end{array}$ & $\begin{array}{l}0.0014 \\
(0.93)\end{array}$ & $\begin{array}{l}0.0014 \\
(0.93)\end{array}$ & $\begin{array}{l}0.0004 \\
(0.21)\end{array}$ & $\begin{array}{l}0.0005 \\
(0.24)\end{array}$ \\
\hline RETURN $_{t-1}$ & $\begin{array}{l}0.1456 \\
(1.48)\end{array}$ & $\begin{array}{l}0.0207 \\
(0.39)\end{array}$ & $\begin{array}{l}0.1958^{* \star *} \\
(4.89)\end{array}$ & $\begin{array}{l}0.1771^{\star \star \star} \\
(8.17)\end{array}$ & $\begin{array}{l}-0.0426 \\
(-0.53)\end{array}$ & $\begin{array}{l}-0.1670^{\star \star \star} \\
(-3.68)\end{array}$ \\
\hline RETURN $_{t-2}$ & $\begin{array}{l}0.1406 \\
(1.07)\end{array}$ & $\begin{array}{l}0.0669 \\
(1.36)\end{array}$ & $\begin{array}{l}0.1341^{* * *} \\
(2.68)\end{array}$ & $\begin{array}{l}0.1420^{\star \star \star} \\
(5.72)\end{array}$ & $\begin{array}{l}0.0252 \\
(0.23)\end{array}$ & $\begin{array}{l}-0.0693 \\
(-1.61)\end{array}$ \\
\hline NUMBER_OF_ARTICLES & $\begin{array}{l}-0.0463^{\star \star \star} \\
(-15.88)\end{array}$ & $\begin{array}{l}-0.0418^{\star \star \star} \\
(-15.91)\end{array}$ & $\begin{array}{l}-0.0210^{\star \star \star} \\
(-13.42)\end{array}$ & $\begin{array}{l}-0.0185^{\star \star \star} \\
(-12.47)\end{array}$ & $\begin{array}{l}-0.0298^{* * \star} \\
(-14.18)\end{array}$ & $\begin{array}{l}-0.0270^{\star * *} \\
(-14.74)\end{array}$ \\
\hline ARTICLE_SENTIMENT & $\begin{array}{l}0.3661^{\star \star \star} \\
(2.84)\end{array}$ & $\begin{array}{l}0.4188^{\star \star \star} \\
(3.44)\end{array}$ & $\begin{array}{l}0.2221^{\star \star \star} \\
(2.95)\end{array}$ & $\begin{array}{l}0.2544^{\star \star \star} \\
(3.49)\end{array}$ & $\begin{array}{l}0.2171^{* *} \\
(2.11)\end{array}$ & $\begin{array}{l}0.2541^{\star \star \star} \\
(2.61)\end{array}$ \\
\hline BREADTH_OF_OWNERSHIP & $\begin{array}{l}0.0829 \\
(0.45)\end{array}$ & $\begin{array}{l}0.0666 \\
(0.36)\end{array}$ & $\begin{array}{l}-0.0237 \\
(-0.24)\end{array}$ & $\begin{array}{l}-0.0271 \\
(-0.27)\end{array}$ & $\begin{array}{l}0.1297 \\
(1.20)\end{array}$ & $\begin{array}{l}0.1149 \\
(1.05)\end{array}$ \\
\hline NUMBER_OF_ANALYSTS & $\begin{array}{l}-0.0186 \\
(-1.25)\end{array}$ & $\begin{array}{l}-0.0193 \\
(-1.31)\end{array}$ & $\begin{array}{l}-0.0110 \\
(-1.27)\end{array}$ & $\begin{array}{l}-0.0110 \\
(-1.28)\end{array}$ & $\begin{array}{l}-0.0146 \\
(-1.55)\end{array}$ & $\begin{array}{l}-0.0152 \\
(-1.63)\end{array}$ \\
\hline ANALYST_DISPERSION & $\begin{array}{l}-1.4019^{\star} \\
(-1.89)\end{array}$ & $\begin{array}{l}-1.4120^{*} \\
(-1.89)\end{array}$ & $\begin{array}{l}-0.9742^{\star \star} \\
(-2.57)\end{array}$ & $\begin{array}{l}-0.9842^{\star \star \star} \\
(-2.58)\end{array}$ & $\begin{array}{l}-0.5065 \\
(-1.03)\end{array}$ & $\begin{array}{l}-0.4981 \\
(-1.00)\end{array}$ \\
\hline INST_OWNERSHIP & $\begin{array}{l}0.1424^{\text {** }} \\
(2.01)\end{array}$ & $\begin{array}{l}0.1382^{*} \\
(1.95)\end{array}$ & $\begin{array}{l}0.0436 \\
(1.09)\end{array}$ & $\begin{array}{l}0.0410 \\
(1.03)\end{array}$ & $\begin{array}{l}0.1225^{\text {** }} \\
(2.76)\end{array}$ & $\begin{array}{l}0.1201^{\star \star \star} \\
(2.70)\end{array}$ \\
\hline $\begin{array}{l}\text { No. of obs. } \\
\text { Adj. } R^{2}\end{array}$ & $\begin{array}{c}196,843 \\
0.22\end{array}$ & $\begin{array}{c}196,843 \\
0.28\end{array}$ & $\begin{array}{c}203,815 \\
0.18\end{array}$ & $\begin{array}{c}203,815 \\
0.21\end{array}$ & $\begin{array}{c}196,843 \\
0.14\end{array}$ & $\begin{array}{c}196,843 \\
0.20\end{array}$ \\
\hline $\begin{array}{l}\text { Quarterly fixed effects } \\
\text { Daily fixed effects } \\
\text { Firm fixed effects }\end{array}$ & $\begin{array}{l}\text { Yes } \\
\text { No } \\
\text { Yes }\end{array}$ & $\begin{array}{l}\text { No } \\
\text { Yes } \\
\text { Yes }\end{array}$ & $\begin{array}{l}\text { Yes } \\
\text { No } \\
\text { Yes }\end{array}$ & $\begin{array}{l}\text { No } \\
\text { Yes } \\
\text { Yes }\end{array}$ & $\begin{array}{l}\text { Yes } \\
\text { No } \\
\text { Yes }\end{array}$ & $\begin{array}{l}\text { No } \\
\text { Yes } \\
\text { Yes }\end{array}$ \\
\hline \multicolumn{7}{|c|}{ Panel B. Excluding Articles Containing Words "Volume," "Turnover," or "Return" } \\
\hline INF_INTANG_DUMMY & $\begin{array}{l}0.0144^{\star \star \star} \\
(5.51)\end{array}$ & $\begin{array}{l}0.0120^{\star \star \star} \\
(5.05)\end{array}$ & $\begin{array}{l}0.0048^{\star \star \star} \\
(3.18)\end{array}$ & $\begin{array}{l}0.0039^{\star \star \star} \\
(2.75)\end{array}$ & $\begin{array}{l}0.0108^{* \star \star} \\
(5.91)\end{array}$ & $\begin{array}{l}0.0092^{\star \star \star} \\
(5.57)\end{array}$ \\
\hline $\begin{array}{l}\text { No. of obs. } \\
\text { Adj. } R^{2}\end{array}$ & $\begin{array}{c}182,080 \\
0.22\end{array}$ & $\begin{array}{c}182,080 \\
0.28\end{array}$ & $\begin{array}{c}188,500 \\
0.18\end{array}$ & $\begin{array}{c}188,500 \\
0.21\end{array}$ & $\begin{array}{c}182,080 \\
0.14\end{array}$ & $\begin{array}{c}182,080 \\
0.20\end{array}$ \\
\hline $\begin{array}{l}\text { Quarterly fixed effects } \\
\text { Daily fixed effects } \\
\text { Firm fixed effects }\end{array}$ & $\begin{array}{c}\text { As in Panel A } \\
\text { Yes } \\
\text { No }\end{array}$ & $\begin{array}{c}\text { As in Panel A } \\
\text { No } \\
\text { Yes }\end{array}$ & $\begin{array}{c}\text { As in Panel A } \\
\text { Yes } \\
\text { No }\end{array}$ & $\begin{array}{c}\text { As in Panel A } \\
\text { No } \\
\text { Yes }\end{array}$ & $\begin{array}{c}\text { As in Panel A } \\
\text { Yes } \\
\text { No }\end{array}$ & $\begin{array}{c}\text { As in Panel A } \\
\text { No } \\
\text { Yes }\end{array}$ \\
\hline
\end{tabular}

and control variables, we exclude articles from newspapers (columns 1 and 2), newswires (columns 3 and 4), or press releases (columns 5 and 6). The results remain significant at the $1 \%$ level for all specifications.

One potential concern is that of reverse causality: Is it possible that news tangibility simply reflects certain patterns in stock performance over the last few 
days (e.g., when newswire articles mention extreme stock returns or trading volume)? To account for this confounding effect, we perform the following analysis. We parse the text of all articles searching for words "volume," "turnover," and "return" (the search is not case sensitive). On average, about 7\% of all articles contain at least one of these words. To the extent that an article is published as a reaction to an unusual return or volume pattern in a stock, it is likely to contain these words. Therefore, we eliminate these articles from our analysis, recompute our intangibility measure on the reduced subsample, and reestimate our regressions. The results are reported in Panel B of Table 2. They are almost identical, both in statistical and economic significance, to those from the main specification.

The main left-hand side variables in Table 2 are standardized by turnover. Such variable construction is by design: We want to measure how strongly shortselling activity responds to the change in turnover, assuming that an increase in turnover on qualitative (quantitative) news is likely to be driven by an increase in noise trading (informed trading). However, it is helpful to evaluate our results using the unscaled variables conditional on a given turnover level. To this purpose, we perform the following matching sample analysis. For every stock and qualitative news day we select a no-news day for the same stock in the same month with the closest magnitude of turnover. We define a dummy variable INTANG_NEWS_DAY as equal to 1 for the original qualitative news day observation, and 0 for the matched no-news day observation. We then regress our unscaled measures of short sellers' trading on this dummy and a set of controls. ${ }^{7}$ We also estimate the matching-sample variant of Table 2, whereby for each stock and qualitative news day we now select the quantitative news day with the closest magnitude of turnover and define the variable INTANG_NEWS_DAY as equal to 1 if the day is a qualitative news day, and 0 if it is the matched quantitative news day.

The results of this analysis are reported in Table 3. In Panel A, the matching sample consists of no-news days, and in Panel B, the sample consists of quantitative news days. The results indicate that qualitative days matter over and above the turnover, as all of the coefficients for INTANG_NEWS_DAY are significant. In other words, a similar level of turnover in the stock does not necessarily generate similar levels of short-selling activity. The source of the turnover still matters for the short sellers' response.

Overall, we find strong evidence that short sellers trade more in both directions (shorting and closing) on days when the news about the company is less quantitative. So far, this result is consistent with both the information hypothesis and the liquidity hypothesis. In the following sections, we investigate the causes of this relation and examine whether it is driven by improved liquidity conditions on days with intangible news (liquidity hypothesis) or whether short sellers obtain an informational advantage on such days (information hypothesis).

\footnotetext{
${ }^{7}$ The number of observations in the regressions is not necessarily even because not all control variables could be computed for all days.
} 
TABLE 3

Matching Sample Analysis of Short-Selling Activity

Table 3 reports the results from the regressions of unscaled measures of short-selling activity on the indicator variable INTANG_NEWS_DAY, which equals 1 if the observation is taken from the sample of days where the stock's intangibility score is above the median (qualitative news days), and 0 if the observation is taken from the sample matched on daily turnover. In Panel A, the matching sample consists of days with no media articles (no-news days), and in Panel B, it consists of days with the tangibility score below the median (quantitative news days). In both cases, for every stock-day observation from the sample of qualitative news days, we select the daily observation from the matching sample that has the same stock and month and is the closest in turnover to the main observation. The control variables are defined as in Table 2. All standard errors are double-clustered at the firm and date levels. The $t$-statistics are reported in parentheses. ${ }^{*},{ }^{\star *}$, and ${ }^{* * *}$ indicate significance at the $10 \%, 5 \%$, and $1 \%$ levels, respectively.

\begin{tabular}{|c|c|c|c|c|c|c|}
\hline \multirow[b]{3}{*}{ Independent Variables } & \multicolumn{6}{|c|}{ Dependent Variables } \\
\hline & \multicolumn{2}{|c|}{$\begin{array}{l}\text { SHORT-SALE_- } \\
\text { TURNOVER } \\
\end{array}$} & \multicolumn{2}{|c|}{ SHORTING } & \multicolumn{2}{|c|}{ CLOSING } \\
\hline & 1 & 2 & 3 & 4 & 5 & 6 \\
\hline \multicolumn{7}{|c|}{ Panel A. Short Sellers' Trading on Qualitative News Days Relative to No-News Days with Similar Turnover } \\
\hline $\begin{array}{c}\text { INTANG_NEWS_DAY } \\
\text { (qualitative news) }\end{array}$ & $\begin{array}{l}0.0155^{\star \star \star} \\
(4.64)\end{array}$ & $\begin{array}{l}0.0144^{\star \star \star} \\
(5.09)\end{array}$ & $\begin{array}{l}0.0098^{\star \star \star} \\
(6.06)\end{array}$ & $\begin{array}{l}0.0098^{\star \star \star} \\
(6.57)\end{array}$ & $\begin{array}{l}0.0058^{\star \star} \\
(2.28)\end{array}$ & $\begin{array}{l}0.0049^{\star \star} \\
(2.19)\end{array}$ \\
\hline SIZE & $\begin{array}{l}-0.2182^{\star \star \star} \\
(-7.79)\end{array}$ & $\begin{array}{l}-0.2202^{\star \star \star} \\
(-7.97)\end{array}$ & $\begin{array}{l}-0.0935^{\star \star \star} \\
(-7.17)\end{array}$ & $\begin{array}{l}-0.0945^{\star \star \star} \\
(-7.26)\end{array}$ & $\begin{array}{l}-0.1222^{\star \star \star} \\
(-7.14)\end{array}$ & $\begin{array}{l}-0.1235^{\star \star \star} \\
(-7.40)\end{array}$ \\
\hline MARKET-TO-BOOK & $\begin{array}{l}0.0124^{*} \\
(1.80)\end{array}$ & $\begin{array}{l}0.0120^{*} \\
(1.74)\end{array}$ & $\begin{array}{l}0.0066^{\star \star} \\
(1.97)\end{array}$ & $\begin{array}{l}0.0066^{\star \star} \\
(2.00)\end{array}$ & $\begin{array}{l}0.0056 \\
(1.58)\end{array}$ & $\begin{array}{l}0.0052 \\
(1.46)\end{array}$ \\
\hline RETURN $_{t-1}$ & $\begin{array}{l}-0.1139 \\
(-0.60)\end{array}$ & $\begin{array}{l}0.2334^{\star \star} \\
(2.00)\end{array}$ & $\begin{array}{l}0.1589^{\star \star} \\
(2.12)\end{array}$ & $\begin{array}{l}0.4047^{\star \star \star} \\
(7.18)\end{array}$ & $\begin{array}{l}-0.2741^{*} \\
(-1.76)\end{array}$ & $\begin{array}{l}-0.1759^{\star} \\
(-1.88)\end{array}$ \\
\hline RETURN $_{t-2}$ & $\begin{array}{l}-0.1672 \\
(-0.72)\end{array}$ & $\begin{array}{l}0.0260 \\
(0.22)\end{array}$ & $\begin{array}{l}0.0604 \\
(0.81)\end{array}$ & $\begin{array}{l}0.2373^{\star \star \star} \\
(4.44)\end{array}$ & $\begin{array}{l}-0.2087 \\
(-1.08)\end{array}$ & $\begin{array}{l}-0.2014^{\star \star} \\
(-2.17)\end{array}$ \\
\hline NUMBER_OF_ARTICLES & $\begin{array}{l}0.0944 \\
(0.28)\end{array}$ & $\begin{array}{l}0.0978 \\
(0.29)\end{array}$ & $\begin{array}{l}-0.0383 \\
(-0.25)\end{array}$ & $\begin{array}{l}-0.0111 \\
(-0.07)\end{array}$ & $\begin{array}{l}0.1255 \\
(0.63)\end{array}$ & $\begin{array}{l}0.1016 \\
(0.51)\end{array}$ \\
\hline ARTICLE_SENTIMENT & $\begin{array}{l}-0.0287 \\
(-1.01)\end{array}$ & $\begin{array}{l}-0.0310 \\
(-1.10)\end{array}$ & $\begin{array}{l}-0.0175 \\
(-1.26)\end{array}$ & $\begin{array}{l}-0.0184 \\
(-1.34)\end{array}$ & $\begin{array}{l}-0.0121 \\
(-0.78)\end{array}$ & $\begin{array}{l}-0.0133 \\
(-0.86)\end{array}$ \\
\hline BREADTH_OF_OWNERSHIP & $\begin{array}{l}7.1616^{\star \star \star} \\
(3.09)\end{array}$ & $\begin{array}{l}7.1788^{\star \star \star} \\
(3.15)\end{array}$ & $\begin{array}{l}2.6386^{\star \star} \\
(2.27)\end{array}$ & $\begin{array}{l}2.5813^{\star \star} \\
(2.26)\end{array}$ & $\begin{array}{l}4.4858^{\star \star \star} \\
(3.48)\end{array}$ & $\begin{array}{l}4.5432^{\star \star \star} \\
(3.55)\end{array}$ \\
\hline NUMBER_OF_ANALYSTS & $\begin{array}{l}0.4256^{\star \star \star} \\
(3.43)\end{array}$ & $\begin{array}{l}0.4283^{\star \star \star} \\
(3.45)\end{array}$ & $\begin{array}{l}0.1500^{\star \star} \\
(2.45)\end{array}$ & $\begin{array}{l}0.1445^{\star \star} \\
(2.36)\end{array}$ & $\begin{array}{l}0.2729^{\star \star \star \star} \\
(4.11)\end{array}$ & $\begin{array}{l}0.2799^{\star \star *} \\
(4.20)\end{array}$ \\
\hline $\begin{array}{l}\text { No. of obs. } \\
\text { Adj. } R^{2}\end{array}$ & $\begin{array}{c}164,175 \\
0.31\end{array}$ & $\begin{array}{c}164,175 \\
0.36\end{array}$ & $\begin{array}{c}170,641 \\
0.26\end{array}$ & $\begin{array}{c}170,641 \\
0.29\end{array}$ & $\begin{array}{c}164,175 \\
0.21\end{array}$ & $\begin{array}{c}164,175 \\
0.28\end{array}$ \\
\hline $\begin{array}{l}\text { Quarterly fixed effects } \\
\text { Daily fixed effects } \\
\text { Firm fixed effects }\end{array}$ & $\begin{array}{l}\text { No } \\
\text { Yes } \\
\text { Yes }\end{array}$ & $\begin{array}{l}\text { Yes } \\
\text { No } \\
\text { Yes }\end{array}$ & $\begin{array}{l}\text { No } \\
\text { Yes } \\
\text { Yes }\end{array}$ & $\begin{array}{l}\text { Yes } \\
\text { No } \\
\text { Yes }\end{array}$ & $\begin{array}{l}\text { No } \\
\text { Yes } \\
\text { Yes }\end{array}$ & $\begin{array}{l}\text { Yes } \\
\text { No } \\
\text { Yes }\end{array}$ \\
\hline \multicolumn{7}{|c|}{ Panel B. Short Sellers' Trading on Qualitative News Days Relative to Quantitative News Days with Similar Turnover } \\
\hline $\begin{array}{c}\text { INTANG_NEWS_DAY } \\
\text { (qualitative news) }\end{array}$ & $\begin{array}{l}0.0085^{\star \star \star} \\
(2.71)\end{array}$ & $\begin{array}{l}0.0064^{\star \star} \\
(2.15)\end{array}$ & $\begin{array}{l}0.0038^{\star \star} \\
(2.34)\end{array}$ & $\begin{array}{l}0.0026 \\
(1.61)\end{array}$ & $\begin{array}{l}0.0052^{\star \star} \\
(2.25)\end{array}$ & $\begin{array}{l}0.0041^{\star \star} \\
(1.98)\end{array}$ \\
\hline $\begin{array}{l}\text { No. of obs. } \\
\text { Adj. } R^{2}\end{array}$ & $\begin{array}{c}196,669 \\
0.33\end{array}$ & $\begin{array}{c}196,669 \\
0.37\end{array}$ & $\begin{array}{c}204,027 \\
0.27\end{array}$ & $\begin{array}{c}204,027 \\
0.30\end{array}$ & $\begin{array}{c}196,669 \\
0.23\end{array}$ & $\begin{array}{c}196,669 \\
0.29\end{array}$ \\
\hline $\begin{array}{l}\text { Controls } \\
\text { Quarterly fixed effects } \\
\text { Daily fixed effects } \\
\text { Firm fixed effects }\end{array}$ & $\begin{array}{c}\text { As in Panel A } \\
\text { No } \\
\text { Yes } \\
\text { Yes }\end{array}$ & $\begin{array}{c}\text { As in Panel A } \\
\text { Yes } \\
\text { No } \\
\text { Yes }\end{array}$ & $\begin{array}{c}\text { As in Panel A } \\
\text { No } \\
\text { Yes } \\
\text { Yes }\end{array}$ & $\begin{array}{c}\text { As in Panel A } \\
\text { Yes } \\
\text { No } \\
\text { Yes }\end{array}$ & $\begin{array}{c}\text { As in Panel A } \\
\text { No } \\
\text { Yes } \\
\text { Yes }\end{array}$ & $\begin{array}{c}\text { As in Panel A } \\
\text { Yes } \\
\text { No } \\
\text { Yes }\end{array}$ \\
\hline
\end{tabular}

\section{News Intangibility and Liquidity}

We now investigate the basic premise of the liquidity hypothesis: The conjecture that intangible information induces noise trading and stimulates liquidity. We proceed in two steps. First, we show that more intangible news has a lower informational content. Second, we show that the trading associated with such noninformational media events increases stock liquidity.

\section{A. News Intangibility and Stock Price Informativeness}

We begin by focusing on the informativeness of intangible news. Standard theory (e.g., Campbell et al. (1993), Llorente et al. (2002), and Tetlock (2010)) suggests that prices tend to mean revert more strongly in the presence of noise 
shocks and tend to mean revert less when the released information is fundamental. We therefore test whether a release of intangible news is associated with a more persistent or a more transient price shock than a release of quantitative news. If the event-day return is a function of noise trading rather than investors' rational reaction to information, we should detect stronger reversals in the days following the news day.

To relate the degree of return reversion to news intangibility, we regress future stock returns on the interaction between information intangibility and the contemporaneous return. Following the standards in the literature, we employ the Fama-MacBeth (1973) regression specification with the Newey-West (1987) correction for autocorrelation. The sample for this regression includes all news days from Jan. 1999 to Dec. 2008.

We consider different horizon lengths (10, 20, and 30 days) and run the regressions for both raw and market-adjusted returns calculated net of the CRSP value-weighted index. Table 4 presents the results. When information intangibility is at its median (i.e., equal to 0 by construction), we observe a consistent reversal effect as evidenced by the negative coefficient in front of the return variable. Most of the reversal occurs in the 10 trading days after the news event day when about $5.2 \%$ of the event-day return is eliminated. Importantly, the coefficient for the interaction of return and information intangibility is negative and significant, suggesting that reversals are stronger when the news day is characterized by qualitative information. An increase in information intangibility by 0.05 increases the 10-day reversal effect from 5.2 to 7.9 percentage points (i.e., the reversal increases by $50 \%) .{ }^{8}$ The results are similar for raw and market-adjusted returns as well as for 20- and 30-day horizons.

These findings suggest that less fundamental information gets permanently incorporated into prices on days with intangible news. In other words, price swings on such days tend to be temporary, consistent with the conjecture that qualitative news has lower informational content and attracts the attention of noise traders rather than investors who are able to evaluate the information accurately.

An alternative approach to assess the informational content of intangible news is simply to study its stock price impact. In Table IA. 2 of the Internet Appendix we present panel regressions of contemporaneous absolute returns and squared returns on information intangibility. We find that the price impact of intangible news is significantly lower than that of quantitative news. An increase in information intangibility by 0.05 decreases the absolute return by 10 basis points, or $8.3 \%$ relative to its median. Also, squared returns are significantly lower on news days with higher information intangibility. This finding is robust to the inclusion of firm and daily fixed effects and suggests that intangible information is perceived as less important by the market. 
TABLE 4

Return Mean Reversion as a Function of Information Intangibility

Table 4 reports the results from daily Fama-MacBeth (1973) regressions with Newey-West (1987) correction that examine how mean reversion of returns is mediated by information intangibility. The dependent variables are returns in the $10-, 20-$, and 30-trading-day windows after day $t$. The explanatory variable of interest is the interaction between the contemporaneous return and information intangibility. In columns 4-6, we use market-adjusted return (MKT_ADJ_RETURN), calculated as the actual return minus the return on the Center for Research in Security Prices (CRSP) value-weighted index. The explanatory variable of interest is INF_INTANG, defined as in Table 2. The control variables are defined as in Table 2. The $t$-statistics are reported in parentheses. ${ }^{*}{ }^{* *}$, and ${ }^{* * *}$ indicate significance at the $10 \%, 5 \%$, and $1 \%$ levels, respectively. The sample for this regression consists of news days from Jan. 1999 to Dec. 2008.

\begin{tabular}{|c|c|c|c|c|c|c|}
\hline \multirow[b]{4}{*}{ Independent Variables } & \multicolumn{6}{|c|}{ Dependent Variables } \\
\hline & \multicolumn{3}{|c|}{ RETURN } & \multicolumn{3}{|c|}{ MKT_ADJ_RETURN } \\
\hline & $t+1$ to $t+10$ & $t+1$ to $t+20$ & $t+1$ to $t+30$ & $t+1$ to $t+10$ & $t+1$ to $t+20$ & $t+1$ to $t+30$ \\
\hline & 1 & 2 & 3 & 4 & 5 & 6 \\
\hline $\begin{array}{l}\text { RETURN } \times \\
\text { INF_INTANG }\end{array}$ & $\begin{array}{l}-0.5317^{* \star *} \\
(-4.34)\end{array}$ & $\begin{array}{l}-0.6185^{\star \star \star} \\
(-3.42)\end{array}$ & $\begin{array}{l}-0.6063^{\text {** }} \\
(-3.12)\end{array}$ & & & \\
\hline $\begin{array}{l}\text { MKT_ADJ_RETURN } \times \\
\text { INF_INTANG }\end{array}$ & & & & $\begin{array}{l}-0.5268^{* * *} \\
(-4.33)\end{array}$ & $\begin{array}{l}-0.5890^{\star \star \star} \\
(-3.24)\end{array}$ & $\begin{array}{l}-0.6046^{\star \star \star} \\
(-3.12)\end{array}$ \\
\hline RETURN & $\begin{array}{l}-0.0518^{* * *} \\
(-6.08)\end{array}$ & $\begin{array}{l}-0.0473^{\star \star *} \\
(-3.43)\end{array}$ & 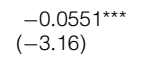 & & & \\
\hline MKT_ADJ_RETURN & & & & $\begin{array}{l}-0.0537^{\star \star \star} \\
(-6.19)\end{array}$ & $\begin{array}{l}-0.0504^{\star \star \star} \\
(-3.55)\end{array}$ & $\begin{array}{l}-0.0579^{* \star *} \\
(-3.24)\end{array}$ \\
\hline INF_INTANG & $\begin{array}{l}-0.0158^{* * *} \\
(-3.86)\end{array}$ & $\begin{array}{l}-0.0303^{\star * \star} \\
(-4.20)\end{array}$ & $\begin{array}{l}-0.0351^{\star \star \star} \\
(-3.69)\end{array}$ & $\begin{array}{l}-0.0163^{* * *} \\
(-4.12)\end{array}$ & $\begin{array}{l}-0.0298^{\star \star \star} \\
(-4.19)\end{array}$ & $\begin{array}{l}-0.0349^{* \star *} \\
(-3.68)\end{array}$ \\
\hline SIZE & $\begin{array}{l}-0.0053^{* \star *} \\
(-6.03)\end{array}$ & $\begin{array}{l}-0.0100^{\star \star \star} \\
(-5.50)\end{array}$ & $\begin{array}{l}-0.0143^{\text {** }} \\
(-5.01)\end{array}$ & $\begin{array}{l}-0.0054^{* \star *} \\
(-6.03)\end{array}$ & 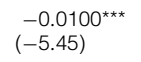 & $\begin{array}{l}-0.0143^{\star * \star} \\
(-4.99)\end{array}$ \\
\hline MARKET-TO-BOOK & $\begin{array}{l}-0.0000 \\
(-0.40)\end{array}$ & $\begin{array}{l}-0.0001 \\
(-0.36)\end{array}$ & $\begin{array}{l}-0.0001 \\
(-0.25)\end{array}$ & $\begin{array}{l}-0.0000 \\
(-0.20)\end{array}$ & $\begin{array}{l}-0.0001 \\
(-0.22)\end{array}$ & $\begin{array}{l}-0.0001 \\
(-0.15)\end{array}$ \\
\hline BREADTH_OF_OWNERSHIP & $\begin{array}{l}0.0294^{\star * \star} \\
(3.90)\end{array}$ & $\begin{array}{l}0.0539^{\star \star *} \\
(3.42)\end{array}$ & $\begin{array}{l}0.0751^{\star \star \star} \\
(3.01)\end{array}$ & $\begin{array}{l}0.0298^{* \star *} \\
(3.86)\end{array}$ & $\begin{array}{l}0.0543^{\star \star \star} \\
(3.34)\end{array}$ & $\begin{array}{l}0.0760^{\star * *} \\
(2.93)\end{array}$ \\
\hline NUMBER_OF_ANALYSTS & $\begin{array}{l}0.0010 \\
(1.10)\end{array}$ & $\begin{array}{l}0.0015 \\
(0.99)\end{array}$ & $\begin{array}{l}0.0024 \\
(1.07)\end{array}$ & $\begin{array}{l}0.0011 \\
(1.20)\end{array}$ & $\begin{array}{l}0.0017 \\
(1.12)\end{array}$ & $\begin{array}{l}0.0027 \\
(1.24)\end{array}$ \\
\hline ANALYST_DISPERSION & $\begin{array}{l}-0.2938^{\star *} \\
(-2.54)\end{array}$ & $\begin{array}{l}-0.5372^{\star \star} \\
(-2.39)\end{array}$ & $\begin{array}{l}-0.6141^{*} \\
(-1.90)\end{array}$ & $\begin{array}{l}-0.3009^{\star \star \star} \\
(-2.61)\end{array}$ & $\begin{array}{l}-0.5466^{\star \star} \\
(-2.40)\end{array}$ & $\begin{array}{l}-0.6298^{*} \\
(-1.91)\end{array}$ \\
\hline INST_OWNERSHIP & $\begin{array}{l}-0.0040^{* *} \\
(-2.27)\end{array}$ & $\begin{array}{l}-0.0071^{\star \star} \\
(-1.99)\end{array}$ & $\begin{array}{l}-0.0106^{*} \\
(-1.85)\end{array}$ & $\begin{array}{l}-0.0042^{\star *} \\
(-2.37)\end{array}$ & $\begin{array}{l}-0.0074^{\star \star} \\
(-1.98)\end{array}$ & $\begin{array}{l}-0.0116^{*} \\
(-1.89)\end{array}$ \\
\hline NUMBER_OF_ARTICLES & $\begin{array}{l}0.0005 \\
(1.25)\end{array}$ & $\begin{array}{l}0.0011 \\
(1.41)\end{array}$ & $\begin{array}{l}0.0016 \\
(1.47)\end{array}$ & $\begin{array}{l}0.0005 \\
(1.16)\end{array}$ & $\begin{array}{l}0.0011 \\
(1.40)\end{array}$ & $\begin{array}{l}0.0015 \\
(1.39)\end{array}$ \\
\hline ARTICLE_SENTIMENT & $\begin{array}{l}0.0312^{*} \\
(1.84)\end{array}$ & $\begin{array}{l}0.0307 \\
(0.86)\end{array}$ & $\begin{array}{l}0.0426 \\
(0.82)\end{array}$ & $\begin{array}{l}0.0300^{*} \\
(1.73)\end{array}$ & $\begin{array}{l}0.0313 \\
(0.87)\end{array}$ & $\begin{array}{l}0.0430 \\
(0.82)\end{array}$ \\
\hline $\begin{array}{l}\text { No. of obs. } \\
\text { Newey-West lags }\end{array}$ & $\begin{array}{l}723,449 \\
10\end{array}$ & $\begin{array}{l}723,409 \\
20\end{array}$ & $\begin{array}{l}723,363 \\
30\end{array}$ & $\begin{array}{l}723,449 \\
10\end{array}$ & $\begin{array}{l}723,409 \\
20\end{array}$ & $\begin{array}{l}723,363 \\
30\end{array}$ \\
\hline
\end{tabular}

\section{B. News Intangibility and Stock Liquidity}

We now study how news intangibility, now ascertained to be associated with lower informational content, affects stock liquidity.

In Table 5, we show the effect of information intangibility on Amihud (2002) illiquidity (in Table IA.3 of the Internet Appendix we show the same regression for the bid-ask spread). The sample period for these regressions includes all news days from Jan. 1999 to Dec. 2008. We consider specifications with either firm and quarter or firm and day fixed effects, and cluster the standard errors at the firm and date level. We also control for lagged liquidity to account for the serial persistence in the liquidity variable.

Our findings indicate a robust and strong negative relation between stock illiquidity and qualitative media content. In other words, liquidity tends to improve on days the information is less tangible. An increase in the fraction of nonnumerical words in news articles by 5 percentage points (about 1 standard 
TABLE 5

Liquidity as a Function of Information Intangibility

Table 5 reports the results from daily panel regressions that examine how information intangibility affects stock liquidity. The dependent variable is daily Amihud (2002) illiquidity (AMIHUD_ILLIQUIDITY), defined as $10^{3} \ln (1+$ $10^{6} \times \mid$ RETURN|/(DOLLAR_VOLUME)). The explanatory variable of interest is INF_INTANG, defined as in Table 2. In Panel $A$, we perform the analysis on the entire sample. In Panel B, we reestimate the regression using INF INTANG calculated after the exclusion of articles containing words "volume," "turnover," or "return." BID-ASK_SPREAD is calculated as mean over_5-min_intervals $_{(}($ASK - BID $) /(0.5 \times$ ASK $+0.5 \times$ BID $\left.)\right)$. The other control variables are defined as in Table 2 . All standard errors are double-clustered at the firm and date levels. The $t$-statistics are reported in parentheses. ${ }^{* *}$ and ${ }^{* * *}$ indicate significance at the $5 \%$ and $1 \%$ levels, respectively. The sample for this regression consists of news days from Jan. 1999 to Dec. 2008.

\begin{tabular}{|c|c|c|c|c|c|}
\hline \multirow[b]{2}{*}{ Independent Variables } & \multicolumn{5}{|c|}{ Dependent Variable: AMIHUD_ILLIQUIDITY } \\
\hline & 1 & 2 & 3 & 4 & 5 \\
\hline \multicolumn{6}{|l|}{ Panel A. Entire Sample } \\
\hline INF_INTANG & $\begin{array}{l}-0.8454^{\text {** }} \\
(-4.89)\end{array}$ & $\begin{array}{l}-0.5649^{\star \star \star} \\
(-3.92)\end{array}$ & $\begin{array}{l}-0.3777^{\star \star \star} \\
(-4.82)\end{array}$ & $\begin{array}{l}-0.3423^{\text {}} \\
(-4.47)\end{array}$ & $\begin{array}{l}-0.2039^{\star \star *} \\
(-3.71)\end{array}$ \\
\hline SIZE & $\begin{array}{l}-0.4390^{\star \star \star} \\
(-23.45)\end{array}$ & $\begin{array}{l}-0.6314^{\star \star \star} \\
(-21.56)\end{array}$ & $\begin{array}{l}-0.6305^{\star \star \star} \\
(-16.34)\end{array}$ & $\begin{array}{l}-0.6303^{\star \star \star} \\
(-16.37)\end{array}$ & 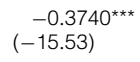 \\
\hline MARKET-TO-BOOK & $\begin{array}{l}-0.0148^{* \star \star} \\
(-4.30)\end{array}$ & $\begin{array}{l}-0.0095^{\star \star \star} \\
(-3.01)\end{array}$ & $\begin{array}{l}-0.0128^{\star \star \star} \\
(-2.91)\end{array}$ & $\begin{array}{l}-0.0128^{\star \star \star} \\
(-2.94)\end{array}$ & $\begin{array}{l}-0.0074^{\star \star \star} \\
(-2.75)\end{array}$ \\
\hline BREADTH_OF_OWNERSHIP & & 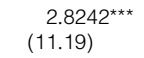 & $\begin{array}{l}1.7627^{\star \star \star} \\
(3.99)\end{array}$ & $\begin{array}{l}1.7712^{\star \star \star} \\
(4.02)\end{array}$ & $\begin{array}{l}0.9114^{\text {** }} \\
(3.37)\end{array}$ \\
\hline NUMBER_OF_ANALYSTS & & $\begin{array}{l}-0.2876^{\star \star \star} \\
(-8.34)\end{array}$ & $\begin{array}{l}-0.1473^{\star \star \star} \\
(-3.22)\end{array}$ & $\begin{array}{l}-0.1461^{\text {}} \\
(-3.20)\end{array}$ & $\begin{array}{l}-0.0884^{\star \star \star} \\
(-3.04)\end{array}$ \\
\hline ANALYST_DISPERSION & & $\begin{array}{l}17.1653^{\text {}} \\
(3.50)\end{array}$ & $\begin{array}{l}23.3601^{\star \star \star} \\
(5.36)\end{array}$ & $\begin{array}{l}23.2743^{\star \star \star} \\
(5.36)\end{array}$ & $\begin{array}{l}13.4520^{\star \star \star} \\
(5.30)\end{array}$ \\
\hline INST_OWNERSHIP & & $\begin{array}{l}-1.5156^{\star \star \star} \\
(-12.91)\end{array}$ & $\begin{array}{l}-1.6264^{\star \star \star} \\
(-8.72)\end{array}$ & $\begin{array}{l}-1.6296^{\star \star \star} \\
(-8.76)\end{array}$ & $\begin{array}{l}-1.0053^{\star \star \star} \\
(-8.67)\end{array}$ \\
\hline NUMBER_OF_ARTICLES & & $\begin{array}{l}0.0470^{\star \star \star} \\
(4.08)\end{array}$ & $\begin{array}{l}0.0140^{\star \star} \\
(2.10)\end{array}$ & $\begin{array}{l}0.0153^{\star \star} \\
(2.24)\end{array}$ & $\begin{array}{l}0.0024 \\
(0.55)\end{array}$ \\
\hline ARTICLE_SENTIMENT & & $\begin{array}{l}0.3943 \\
(0.88)\end{array}$ & $\begin{array}{l}-0.3957 \\
(-1.63)\end{array}$ & $\begin{array}{l}-0.2732 \\
(-1.15)\end{array}$ & $\begin{array}{l}0.1098 \\
(0.64)\end{array}$ \\
\hline AMIHUD_ILLIQUIDITY ${ }_{t-1}$ & & & & & $\begin{array}{l}0.3500^{\star \star \star} \\
(44.89)\end{array}$ \\
\hline BID-ASK_SPREAD ${ }_{t-1}$ & & & & & $\begin{array}{l}0.2461^{\star \star \star} \\
(13.91)\end{array}$ \\
\hline $\begin{array}{l}\text { No. of obs. } \\
\text { Adj. } R^{2}\end{array}$ & $\begin{array}{c}833,686 \\
0.26\end{array}$ & $\begin{array}{c}723,487 \\
0.33\end{array}$ & $\begin{array}{c}723,487 \\
0.43\end{array}$ & $\begin{array}{c}723,487 \\
0.44\end{array}$ & $\begin{array}{c}722,096 \\
0.52\end{array}$ \\
\hline $\begin{array}{l}\text { Daily fixed effects } \\
\text { Quarterly fixed effects } \\
\text { Firm fixed effects }\end{array}$ & $\begin{array}{l}\text { Yes } \\
\text { No } \\
\text { No }\end{array}$ & $\begin{array}{l}\text { Yes } \\
\text { No } \\
\text { No }\end{array}$ & $\begin{array}{l}\text { No } \\
\text { Yes } \\
\text { Yes }\end{array}$ & $\begin{array}{l}\text { Yes } \\
\text { No } \\
\text { Yes }\end{array}$ & $\begin{array}{l}\text { Yes } \\
\text { No } \\
\text { Yes }\end{array}$ \\
\hline \multicolumn{6}{|c|}{ Panel B. Excluding Articles Containing Words "Volume," "Turnover," or "Return" } \\
\hline INF_INTANG & $\begin{array}{l}-0.7619^{\text {** }} \\
(-4.63)\end{array}$ & $\begin{array}{l}-0.5362^{\star \star \star} \\
(-3.84)\end{array}$ & $\begin{array}{l}-0.3909^{\star \star \star} \\
(-5.14)\end{array}$ & $\begin{array}{l}-0.3533^{\star \star \star} \\
(-4.73)\end{array}$ & $\begin{array}{l}-0.2127^{\star \star \star} \\
(-3.99)\end{array}$ \\
\hline $\begin{array}{l}\text { No. of obs. } \\
\text { Adj. } R^{2}\end{array}$ & $\begin{array}{c}766,106 \\
0.26\end{array}$ & $\begin{array}{c}665,735 \\
0.33\end{array}$ & $\begin{array}{c}665,735 \\
0.43\end{array}$ & $\begin{array}{c}665,735 \\
0.45\end{array}$ & $\begin{array}{c}664,456 \\
0.52\end{array}$ \\
\hline $\begin{array}{l}\text { Controls } \\
\text { Daily fixed effects } \\
\text { Quarterly fixed effects } \\
\text { Firm fixed effects }\end{array}$ & $\begin{array}{c}\text { As in Panel A } \\
\text { Yes } \\
\text { No } \\
\text { No }\end{array}$ & $\begin{array}{c}\text { As in Panel A } \\
\text { Yes } \\
\text { No } \\
\text { No }\end{array}$ & $\begin{array}{c}\text { As in Panel A } \\
\text { No } \\
\text { Yes } \\
\text { Yes }\end{array}$ & $\begin{array}{c}\text { As in Panel A } \\
\text { Yes } \\
\text { No } \\
\text { Yes }\end{array}$ & $\begin{array}{c}\text { As in Panel A } \\
\text { Yes } \\
\text { No } \\
\text { Yes }\end{array}$ \\
\hline
\end{tabular}

deviation) results in a decrease of Amihud (2002) illiquidity by $21 \%$ relative to its median. ${ }^{9}$ The results are robust to the inclusion of firm fixed effects and lags of dependent variables.

As in the previous section, we repeat our analysis for the reduced subsample, which is likely free from potential reverse causality issues. In Panel B of Table 5 (Table IA. 3 of the Internet Appendix), we report the effect of information 
intangibility on Amihud illiquidity (bid-ask spread) in the subsample of articles that do not contain words "volume," "turnover," or "return." Our results remain significant and consistent across the specifications.

On the whole, this evidence strongly suggests that liquidity rises on the arrival of intangible news. One plausible explanation for the observed relation between news intangibility and liquidity is an increase in public attention to the company combined with highly dispersed interpretations of the news content. The more people are attracted to the stock, the higher the liquidity, provided that a significant fraction of the investors trade in opposite directions. We can therefore argue that, from the point of view of an informed investor, the behavior of the market on days with intangible news is akin to an influx of noise traders.

To substantiate this argument, our next test relates liquidity conditions in the sense of Kyle (1985), Amihud illiquidity estimated at a monthly frequency, to the fraction of qualitative news days in the month and differently weighted news intangibility. We construct a panel of stock-month observations and regress Amihud illiquidity on the fraction of qualitative news days (out of all trading days of the month), the fraction of quantitative news days, the simple average of daily intangibility scores, and the weighted average of daily intangibility scores, where the weight of each day is proportional to the number of articles about the company that appeared on that day. The last variable takes into account the volume of news in addition to the type of news. All specifications feature firm fixed effects and double-clustered standard errors at the stock-quarter level.

Table 6 presents the results. As predicted, information intangibility, whether actual or proxied by the fraction of qualitative news days (i.e., days with the above-median intangibility), is strongly associated with lower illiquidity (higher liquidity). The coefficient for the fraction of quantitative news days has the opposite sign but is not significant. This result is not inconsistent with our theoretical predictions, because quantitative news is likely to attract both uninformed and newly informed traders. The net effect of purely quantitative news on liquidity is therefore ambiguous, both theoretically and empirically.

We note that the evidence in this section plays an important part in our argument because it is essential to distinguish between liquidity and turnover. For an informed investor looking to disguise trades, an increase in the stock's trading volume is not a sufficient condition; the investor still needs to know what causes the increase in turnover. For example, turnover does go up when there is extra uninformed attention to the stock but it can also go up when informed investors start to trade more actively (Karpoff (1986), Admati and Pfleiderer (1988), and Foster and Viswanathan (1990)). The latter effect is observed during the release of quantitative information when a large number of market participants receive the same signal and rush to execute their orders, thereby competing for a limited amount of liquidity. 
TABLE 6

Monthly Liquidity and the Day's News Type

Table 6 reports the results from monthly panel regressions of Amihud (2002) illiquidity on several variables of interest related to information intangibility. The dependent variable is AMIHUD_ILLIQUIDITY estimated over all the trading days of the month. The independent variables are defined as follows. FRACTION_OF_QUALNEWS (FRACTION OF QUANTNEWS) is defined as the ratio of the number of days with an above-median (below-median) intangibility score to the total number of trading days in the month. INF_INTANG (simple average) is computed as the simple average of intangibility scores over all the news days in the month, and INF_INTANG (weighted average) is computed as the weighted average of such intangibility scores where the weight of each day is proportional to the number of articles about the company that appeared on that day. The control variables are defined as in Table 2. All control variables, except NUMBER_OF_ARTICLES, are taken as of the last trading day of the month. All standard errors are double-clustered at the firm and quarter levels. The $t$-statistics are reported in parentheses. ${ }^{*}{ }^{* *}$, and ${ }^{* * *}$ indicate significance at the $10 \%, 5 \%$, and $1 \%$ levels, respectively. The sample for this regression consists of news days from Jan. 1999 to Dec. 2008.

\begin{tabular}{|c|c|c|c|c|}
\hline \multirow[b]{2}{*}{ Independent Variables } & \\
\hline & 1 & 2 & 3 & 4 \\
\hline FRACTION_OF_QUALNEWS & $\begin{array}{l}-0.4517^{\star \star} \\
(-2.14)\end{array}$ & & & \\
\hline FRACTION_OF_QUANTNEWS & & $\begin{array}{l}0.1465 \\
(0.58)\end{array}$ & & \\
\hline INF_INTANG (simple average) & & & $\begin{array}{l}-11.4144^{\star \star \star} \\
(-7.82)\end{array}$ & \\
\hline INF_INTANG (weighted average) & & & & $\begin{array}{l}-11.7588^{\star \star \star} \\
(-7.81)\end{array}$ \\
\hline SIZE & $\begin{array}{l}-4.4818^{\star \star *} \\
(-16.35)\end{array}$ & $\begin{array}{l}-4.4832^{\text {** }} \\
(-16.38)\end{array}$ & $\begin{array}{l}-4.4572^{\star \star \star} \\
(-16.31)\end{array}$ & $\begin{array}{l}-4.4435^{\star \star \star} \\
(-16.21)\end{array}$ \\
\hline MARKET-TO-BOOK & $\begin{array}{l}0.0482^{\star \star} \\
(2.66)\end{array}$ & $\begin{array}{l}0.0491^{* *} \\
(2.70)\end{array}$ & $\begin{array}{l}0.0369^{\star \star} \\
(2.07)\end{array}$ & $\begin{array}{l}0.0363^{\star \star} \\
(2.04)\end{array}$ \\
\hline BREADTH_OF_OWNERSHIP & $\begin{array}{l}12.6510^{\star \star \star} \\
(4.46)\end{array}$ & $\begin{array}{l}12.5762^{\star \star \star} \\
(4.45)\end{array}$ & $\begin{array}{l}13.3372^{\star \star \star} \\
(4.75)\end{array}$ & $\begin{array}{l}13.1775^{\star \star \star} \\
(4.68)\end{array}$ \\
\hline NUMBER_OF_ANALYSTS & $\begin{array}{l}-0.4613^{*} \\
(-1.94)\end{array}$ & $\begin{array}{l}-0.4631^{*} \\
(-1.95)\end{array}$ & $\begin{array}{l}-0.4713^{\star} \\
(-2.01)\end{array}$ & $\begin{array}{l}-0.4935^{\star \star} \\
(-2.12)\end{array}$ \\
\hline ANALYST_DISPERSION & $\begin{array}{l}2.7769 \\
(0.27)\end{array}$ & $\begin{array}{l}2.7387 \\
(0.27)\end{array}$ & $\begin{array}{l}3.7839 \\
(0.36)\end{array}$ & $\begin{array}{l}4.0385 \\
(0.38)\end{array}$ \\
\hline INST_OWNERSHIP & $\begin{array}{l}-10.2982^{\star \star \star} \\
(-7.70)\end{array}$ & $\begin{array}{l}-10.3138^{\star \star *} \\
(-7.69)\end{array}$ & $\begin{array}{l}-9.7763^{\star \star \star} \\
(-7.52)\end{array}$ & $\begin{array}{l}-9.7313^{\star \star \star} \\
(-7.49)\end{array}$ \\
\hline NUMBER_OF_ARTICLES & $\begin{array}{l}-0.2727^{\star \star \star} \\
(-4.74)\end{array}$ & $\begin{array}{l}-0.3197^{* * *} \\
(-4.85)\end{array}$ & $\begin{array}{l}-0.3103^{\text {** }} \\
(-5.66)\end{array}$ & $\begin{array}{l}-0.3289^{\star \star \star} \\
(-5.95)\end{array}$ \\
\hline $\begin{array}{l}\text { No. of obs. } \\
\text { Adj. } R^{2}\end{array}$ & $\begin{array}{c}81,253 \\
0.76\end{array}$ & $\begin{array}{c}81,253 \\
0.76\end{array}$ & $\begin{array}{c}81,253 \\
0.77\end{array}$ & $\begin{array}{c}81,253 \\
0.77\end{array}$ \\
\hline Firm fixed effects & Yes & Yes & Yes & Yes \\
\hline
\end{tabular}

\section{Summer Olympic Games as a Natural Experiment}

The previous results suggest that intangible information causes an increase in noise trading and liquidity. If this is the case, we would expect the effect of intangible news on liquidity to be reduced when the attention of potential noise traders, such as uninformed household investors, is diverted elsewhere. More specifically, noise traders will be less likely to respond to company-specific news if their attention is drawn to a big external event, preferably not related to financial markets. Following Eisensee and Strömberg (2007), we use the Summer Olympic Games as an exogenous and lasting event commanding significant public attention.

Using the Summer Olympic Games as our natural experiment has three important advantages. First, the Olympics is the single most important sport event for Americans. It commands more attention and media coverage than the Super Bowl or the NBA playoffs (Eisensee and Strömberg (2007)). Second, other major news events such as wars, catastrophes, and elections often have large economic implications, and thus might be related to stock liquidity directly. The Olympic Games, conversely, are pure sport events, whose outcomes have no real economic effects 
(except, potentially, for companies manufacturing sport-related items). Third, the Olympic Games play out over a clearly defined time frame; thus, we do not need to make assumptions about the attention span of a stand-alone event. For these reasons, the Summer Olympic Games provide a good natural experiment to test our hypotheses.

We rerun our liquidity regressions interacting information intangibility with a dummy that equals 1 if the news day falls in the 3-week period of the Summer Olympic Games, and 0 otherwise. Table 7 reports the results for Amihud (2002) illiquidity (Table IA.4 of the Internet Appendix reports the same regression for the bid-ask spread). The interaction between information intangibility and the Olympic Games dummy is always positive, suggesting that the relation between news intangibility and liquidity is significantly reduced during the Olympic Games. This result is consistent across all specifications and measures of liquidity and is statistically significant. The interaction coefficient is larger in absolute terms than the coefficient on information intangibility, indicating that the effect of intangible news on liquidity is completely eliminated during the Olympic Games.

\title{
TABLE 7
}

Effect of Olympic Games on the Relation between Liquidity and Information Intangibility

\begin{abstract}
Table 7 reports the results from daily panel regressions that examine how the relation between liquidity and information intangibility changes during the Olympic Games. The dependent variable is daily AMIHUD_ILLIQUIDITY. The explanatory variable of interest is INF_INTANG interacted with a dummy variable equal to 1 during the Olympic Games (OLYMPIC_DUMMY). In column 4, we add four fixed effects for the quarters within a year and interact them with INF_INTANG. The control variables are defined as in Table 2. All standard errors are double-clustered at the firm and date levels. The $t$-statistics are reported in parentheses. *, ${ }^{\star *}$, and ${ }^{* * *}$ indicate significance at the $10 \%, 5 \%$, and $1 \%$ levels, respectively. The sample for this regression consists of news days from Jan. 1999 to Dec. 2008.
\end{abstract}

Independent Variables

INF_INTANG $\times$ OLYMPIC_DUMMY

INF_INTANG

OLYMPIC_DUMMY

SIZE

MARKET-TO-BOOK

BREADTH_OF_OWNERSHIP

NUMBER_OF_ANALYSTS

ANALYST_DISPERSION

INST_OWNERSHIP

NUMBER_OF_ARTICLES

ARTICLE_SENTIMENT

No. of obs.

Adj. $R^{2}$

Quarterly fixed effects

Firm fixed effects

Daily fixed effects

Quarterly fixed effects $\times$ INF_INTANG
Dependent Variable: AMIHUD_ILLIQUIDITY

\begin{tabular}{|c|c|c|c|}
\hline 1 & 2 & 3 & 4 \\
\hline $\begin{array}{l}0.5235^{\star \star} \\
(2.27)\end{array}$ & $\begin{array}{l}0.6429^{\star \star \star} \\
(2.69)\end{array}$ & $\begin{array}{l}0.4694^{\star} \\
(1.80)\end{array}$ & $\begin{array}{l}0.4167^{\star} \\
(1.71)\end{array}$ \\
\hline $\begin{array}{l}-0.4541^{\star \star \star} \\
(-5.12)\end{array}$ & $\begin{array}{l}-0.3891^{\star \star \star} \\
(-4.95)\end{array}$ & $\begin{array}{l}-0.3507^{\star \star \star} \\
(-4.57)\end{array}$ & \\
\hline $\begin{array}{l}0.0033 \\
(0.13)\end{array}$ & $\begin{array}{l}0.0189 \\
(0.72)\end{array}$ & $\begin{array}{l}28.5859 \\
(0.00)\end{array}$ & $\begin{array}{l}0.0151 \\
(0.57)\end{array}$ \\
\hline $\begin{array}{l}-0.6438^{\star \star *} \\
(-18.05)\end{array}$ & $\begin{array}{l}-0.6304^{\star \star \star} \\
(-16.34)\end{array}$ & $\begin{array}{l}-0.6302^{\star \star \star} \\
(-16.36)\end{array}$ & $\begin{array}{l}-0.6296^{\star \star \star} \\
(-16.32)\end{array}$ \\
\hline \multirow[t]{7}{*}{$\begin{array}{l}-0.0152^{\star \star \star} \\
(-3.71)\end{array}$} & $\begin{array}{l}-0.0128^{\star \star \star} \\
(-2.91)\end{array}$ & $\begin{array}{l}-0.0128^{\star \star \star} \\
(-2.94)\end{array}$ & $\begin{array}{l}-0.0128^{\star \star \star} \\
(-2.91)\end{array}$ \\
\hline & $\begin{array}{l}1.7623^{\star \star \star *} \\
(3.99)\end{array}$ & $\begin{array}{l}1.7709^{\star \star \star *} \\
(4.02)\end{array}$ & $\begin{array}{l}1.7555^{\star \star \star} \\
(3.98)\end{array}$ \\
\hline & $\begin{array}{l}-0.1473^{\star \star \star} \\
(-3.22)\end{array}$ & $\begin{array}{l}-0.1461^{\star \star \star} \\
(-3.20)\end{array}$ & $\begin{array}{l}-0.1470^{\star \star \star} \\
(-3.21)\end{array}$ \\
\hline & $\begin{array}{l}23.3606^{\star \star \star} \\
(5.36)\end{array}$ & $\begin{array}{l}23.2746^{\star \star \star} \\
(5.36)\end{array}$ & $\begin{array}{l}23.3713^{\star \star \star} \\
(5.36)\end{array}$ \\
\hline & $\begin{array}{l}-1.6266^{\star \star \star} \\
(-8.72)\end{array}$ & $\begin{array}{l}-1.6298^{\star \star \star} \\
(-8.76)\end{array}$ & $\begin{array}{l}-1.6270^{\star \star \star} \\
(-8.72)\end{array}$ \\
\hline & $\begin{array}{l}0.0140^{\star \star} \\
(2.10)\end{array}$ & $\begin{array}{l}0.0152^{\star \star} \\
(2.24)\end{array}$ & $\begin{array}{l}0.0139^{\star \star} \\
(2.08)\end{array}$ \\
\hline & $\begin{array}{l}-0.3943 \\
(-1.62)\end{array}$ & $\begin{array}{l}-0.2723 \\
(-1.14)\end{array}$ & $\begin{array}{l}-0.3918 \\
(-1.61)\end{array}$ \\
\hline $\begin{array}{c}833,686 \\
0.43\end{array}$ & $\begin{array}{c}723,487 \\
0.43\end{array}$ & $\begin{array}{c}723,487 \\
0.44\end{array}$ & $\begin{array}{c}723,487 \\
0.43\end{array}$ \\
\hline Yes & Yes & No & Yes \\
\hline Yes & Yes & Yes & Yes \\
\hline No & No & Yes & No \\
\hline No & No & No & Yes \\
\hline
\end{tabular}


One potential concern in using the Olympic Games as a natural experiment is that they always take place in the summer. Accordingly, our results might reflect a seasonality effect. To address this issue, we include four dummy variables for the calendar quarters in our regression and interact these dummy variables with information intangibility. This way, we control for the possibility that information intangibility might have a different effect on liquidity in different quarters. Our results remain significant in this conservative setup, suggesting that the Summer Olympic Games also reduce the effect of information intangibility compared to days within the same quarter. Overall, these results show that if potential noise traders are distracted by the Olympic Games, the effect of information intangibility on liquidity disappears, confirming the role of attention and noise trading in generating excess liquidity on intangible news days.

\section{Drivers of Short Sellers' Trading}

The results in the previous section document a link between news intangibility and noise trading and liquidity. We now investigate the nature of short sellers' reaction to intangible news and try to differentiate between our two main hypotheses. We proceed in two steps: First, we test the information hypothesis, and second, we focus on the liquidity hypothesis.

\section{A. Profitability of Short Sellers' Trades}

We start by examining the alternative that short sellers trade on intangible news for information rather than liquidity reasons. Engelberg et al. (2012) show that short sellers' trades are more profitable on news days, suggesting they have an advantage in processing public news. We replicate Engelberg et al.'s findings within our sample, confirming that short sellers are indeed better able to process public information in general (the results are reported in Internet Appendix IA.3). Then, we zoom in on the type of news and ask whether short sellers have a relative advantage in interpreting intangible news compared to tangible news. Such a relative advantage in interpreting intangible news would be necessary to explain why short sellers trade more actively on qualitative compared to quantitative news. Informationally motivated trades would imply that short sellers are able to establish more profitable positions after qualitative news. Therefore, we study whether short sellers' actions anticipate the future stock price movement better on intangible news days. If this were the case, an information-based explanation of their reaction to intangible news would be likely.

We employ a set of Fama-MacBeth (1973) specifications whereby we regress future stock returns at different horizons relative to the news day on our directional measures of short sellers' trading and their interaction with the news intangibility variable. We consider two measures of short sellers' trading: SHORTING_DUMMY, equal to 1 if the percentage of shares outstanding newly shorted on the day is above the median, and REL_SHORTING_DUMMY, equal to 1 if the percentage of total turnover on the day due to the new short positions is above the median.

The results are reported in Table 8, where we concentrate on the 20-tradingday horizon (Table IA.5 of the Internet Appendix shows the results for the 10- and 
TABLE 8

Short-Selling Profitability as a Function of Information Intangibility

Table 8 reports the results from daily Fama-MacBeth (1973) regressions with Newey-West (1987) correction that examine how short sellers' profitability is mediated by information intangibility. We regress future returns over the 20 -trading-day horizon on INF_INTANG interacted with SHORTING_DUMMY, which equals 1 if the fraction of shares outstanding newly shorted is above the median, and REL SHORTING DUMMY, which equals 1 if the fraction of total turnover due to new shorting is above the median. In columns 1 and 2 ( 3 and 4 ) we use raw (market-adjusted) returns. The control variables are defined as in Table 2. The $t$-statistics are reported in parentheses. ${ }^{*},{ }^{* *}$, and ${ }^{* * *}$ indicate significance at the $10 \%, 5 \%$, and $1 \%$ levels, respectively. The sample for this regression consists of news days from July 2006 to Dec. 2008 (excluding the time of the short-sale ban from Sept. 19, 2008 to Oct. 8, 2008).

Dependent Variables $(t+1$ to $t+20)$

\begin{tabular}{|c|c|c|c|c|}
\hline \multirow[b]{2}{*}{ Independent Variables } & \multicolumn{2}{|c|}{ RETURN } & \multicolumn{2}{|c|}{ MKT_ADJ_RETURN } \\
\hline & 1 & 2 & 3 & 4 \\
\hline SHORTING_DUMMY × INF_INTANG & $\begin{array}{l}0.0077 \\
(0.48)\end{array}$ & & $\begin{array}{l}0.0063 \\
(0.38)\end{array}$ & \\
\hline REL_SHORTING_DUMMY $\times$ INF_INTANG & & $\begin{array}{l}-0.0036 \\
(-0.27)\end{array}$ & & $\begin{array}{l}-0.0040 \\
(-0.30)\end{array}$ \\
\hline SHORTING_DUMMY & $\begin{array}{l}-0.0036^{\star \star *} \\
(-2.70)\end{array}$ & & $\begin{array}{l}-0.0033^{\star \star} \\
(-2.34)\end{array}$ & \\
\hline REL_SHORTING_DUMMY & & $\begin{array}{l}-0.0029^{* \star} \\
(-2.40)\end{array}$ & & $\begin{array}{l}-0.0028^{\star \star} \\
(-2.27)\end{array}$ \\
\hline INF_INTANG & $\begin{array}{l}-0.0172 \\
(-1.55)\end{array}$ & $\begin{array}{l}-0.0070 \\
(-0.60)\end{array}$ & $\begin{array}{l}-0.0189 \\
(-1.64)\end{array}$ & $\begin{array}{l}-0.0092 \\
(-0.77)\end{array}$ \\
\hline SIZE & $\begin{array}{l}-0.0098^{\star \star *} \\
(-3.50)\end{array}$ & $\begin{array}{l}-0.0096^{* \star \star} \\
(-3.39)\end{array}$ & $\begin{array}{l}-0.0099^{* * *} \\
(-3.49)\end{array}$ & $\begin{array}{l}-0.0097^{\star \star \star} \\
(-3.39)\end{array}$ \\
\hline MARKET-TO-BOOK & $\begin{array}{l}0.0005^{*} \\
(1.68)\end{array}$ & $\begin{array}{l}0.0004 \\
(1.56)\end{array}$ & $\begin{array}{l}0.0004 \\
(1.54)\end{array}$ & $\begin{array}{l}0.0004 \\
(1.43)\end{array}$ \\
\hline RETURN $_{t-1}$ & $\begin{array}{l}-0.0297 \\
(-1.06)\end{array}$ & $\begin{array}{l}-0.0303 \\
(-1.08)\end{array}$ & $\begin{array}{l}-0.0300 \\
(-1.04)\end{array}$ & $\begin{array}{l}-0.0308 \\
(-1.06)\end{array}$ \\
\hline RETURN $_{t-2}$ & $\begin{array}{l}-0.0185 \\
(-0.61)\end{array}$ & $\begin{array}{l}-0.0188 \\
(-0.62)\end{array}$ & $\begin{array}{l}-0.0191 \\
(-0.60)\end{array}$ & $\begin{array}{l}-0.0194 \\
(-0.61)\end{array}$ \\
\hline BREADTH_OF_OWNERSHIP & $\begin{array}{l}0.0880^{* \star *} \\
(2.94)\end{array}$ & $\begin{array}{l}0.0884^{\star \star \star} \\
(2.97)\end{array}$ & $\begin{array}{l}0.0902^{* * *} \\
(2.93)\end{array}$ & $\begin{array}{l}0.0904^{\star \star *} \\
(2.96)\end{array}$ \\
\hline NUMBER_OF_ANALYSTS & $\begin{array}{l}0.0021 \\
(0.80)\end{array}$ & $\begin{array}{l}0.0016 \\
(0.60)\end{array}$ & $\begin{array}{l}0.0021 \\
(0.82)\end{array}$ & $\begin{array}{l}0.0017 \\
(0.64)\end{array}$ \\
\hline ANALYST_DISPERSION & $\begin{array}{l}-0.2806 \\
(-0.82)\end{array}$ & $\begin{array}{l}-0.3116 \\
(-0.90)\end{array}$ & $\begin{array}{l}-0.2355 \\
(-0.67)\end{array}$ & $\begin{array}{l}-0.2648 \\
(-0.75)\end{array}$ \\
\hline INST_OWNERSHIP & $\begin{array}{l}-0.0046 \\
(-0.46)\end{array}$ & $\begin{array}{l}-0.0055 \\
(-0.56)\end{array}$ & $\begin{array}{l}-0.0068 \\
(-0.62)\end{array}$ & $\begin{array}{l}-0.0077 \\
(-0.72)\end{array}$ \\
\hline NUMBER_OF_ARTICLES & $\begin{array}{l}-0.0013 \\
(-1.00)\end{array}$ & $\begin{array}{l}-0.0014 \\
(-1.13)\end{array}$ & $\begin{array}{l}-0.0013 \\
(-1.04)\end{array}$ & $\begin{array}{l}-0.0015 \\
(-1.17)\end{array}$ \\
\hline ARTICLE_SENTIMENT & $\begin{array}{l}0.0355 \\
(0.50)\end{array}$ & $\begin{array}{l}0.0388 \\
(0.55)\end{array}$ & $\begin{array}{l}0.0290 \\
(0.40)\end{array}$ & $\begin{array}{l}0.0319 \\
(0.44)\end{array}$ \\
\hline $\begin{array}{l}\text { No. of obs. } \\
\text { Newey-West lags }\end{array}$ & $\begin{array}{l}203,778 \\
20\end{array}$ & $\begin{array}{l}203,778 \\
20\end{array}$ & $\begin{array}{l}203,778 \\
20\end{array}$ & $\begin{array}{l}203,778 \\
20\end{array}$ \\
\hline
\end{tabular}

30-day horizons). First, we observe that both measures of short selling are strongly associated with negative future returns when information intangibility assumes its median value ( 0 by construction). This result is consistent with the earlier studies that document a negative relation between short selling and future returns (Engelberg et al. (2012), Cohen et al. (2007), and Diether et al. (2009)). However, we cannot detect any evidence that information intangibility either dampens or enhances this effect, as the interaction coefficients lack both statistical and economic significance. Many of the interaction coefficients are actually positive, indicating a(n) (insignificantly) lower profitability on days with intangible information. The result is robust to considering forward-looking return windows of 10, 20, and 30 trading days. Overall, this evidence suggests that short sellers do not possess 
a greater advantage in interpreting intangible news relative to tangible news but likely increase trading because of improved liquidity conditions.

Importantly, in addition to improving liquidity conditions, qualitative news also serves as an observable signal to the short seller. Without such a signal, even if a short seller were somehow able to disentangle trading data, such as turnover, into noise driven and information driven, it is unlikely that he would be able to do so in time to place his trades. By the time he observes a spike in turnover and conducts a reliable analysis that reveals an influx of noise traders (e.g., Amihud illiquidity is not estimated instantaneously but over a sample of observations), it might be too late to execute a viable trading strategy. However, after observing qualitative news, the short seller is aware that the increase in turnover that is about to follow will likely be noise driven and therefore suitable for trade concealment.

\section{B. Two Natural Experiments}

We now focus on the liquidity hypothesis directly. We consider two natural experiments: The Olympic Games and the addition of a stock to the S\&P 500 index.

We start with the Olympic Games. In Section IV.C, we show that intangible news does not increase liquidity if the attention of noise traders is diverted by the external event of a sporting nature. Therefore, if the increased trading of short sellers on qualitative news days is driven by liquidity, we would expect this relation to break down during the Olympic Games as well. Because our shorter sample of short-selling data includes only one occurrence of the Olympic Games, we cannot construct an independently strong test and simply split the sample into days during the Olympic Games and all other days. The results are reported in Table 9 for the main measure REL_SHORT-SALE_TURNOVER and in Table IA.6 of the Internet Appendix for REL_SHORTING and REL_CLOSING. The evidence indicates that although there is a positive effect of information intangibility on all three measures of short-selling activity in the overall sample, this effect disappears during the Olympic Games. In this period, short sellers' trading is not significantly related to information intangibility (all coefficients are actually negative but insignificant). ${ }^{10}$ This finding is consistent with the liquidity hypothesis because it highlights the role of attention and noise trading in increasing short sellers' activity on qualitative news days.

Next, we consider the S\&P 500 addition. Another prediction of the liquidity hypothesis is that the relation between information intangibility and short sellers' trading should be stronger for stocks that are ex ante less liquid and require an attention event to boost liquidity. To test this prediction, we consider a measure of stock liquidity based on its association with a market index that is actively traded by index funds and other institutions that track the index. Specifically, we define a dummy variable as equal to 1 if the stock is a member of the S\&P 500 index on the news day, and 0 otherwise. We reestimate our main regression, interacting information intangibility with the S\&P 500 dummy. The sample period ranges from July 2006 to Dec. 2008. Because we include firm fixed effects in all regressions,

\footnotetext{
${ }^{10}$ Because we have only one occurrence of the Olympic Games, (time-varying) firm-specific controls are collinear with firm fixed effects in the Olympic Games sample and are thus omitted.
} 
TABLE 9

Short Selling as a Function of Information Intangibility: The Effect of Olympic Games

Table 9 reports the results from daily panel regressions that examine how the relation between information intangibility and short sellers' trading changes during the Olympic Games. In columns 1 and 3, the regression is run only on the subsample of days during the Olympic Games. In columns 2 and 4, the regression is run on the subsample of days when the Olympic Games are not held. The dependent variable is REL SHORT-SALE_TURNOVER, defined as in Table 2. The control variables are defined as in Table 2. All standard errors are double-clustered at the firm and date levels. The $t$-statistics are reported in parentheses. ${ }^{*},{ }^{* *}$, and ${ }^{* * *}$ indicate significance at the $10 \%, 5 \%$, and $1 \%$ levels, respectively. The sample for this regression consists of news days from July 2006 to Dec. 2008.

\begin{tabular}{|c|c|c|c|c|}
\hline \multirow{3}{*}{ Independent Variables } & \multicolumn{4}{|c|}{ Dependent Variable: REL_SHORT-SALE_TURNOVER } \\
\hline & Olympic Games & $\begin{array}{c}\text { No Olympic } \\
\text { Games }\end{array}$ & Olympic Games & $\begin{array}{c}\text { No Olympic } \\
\text { Games }\end{array}$ \\
\hline & 1 & 2 & 3 & 4 \\
\hline INF_INTANG_DUMMY & $\begin{array}{l}-0.0006 \\
(-0.04)\end{array}$ & $\begin{array}{l}0.0121^{\text {***}} \\
(4.87)\end{array}$ & $\begin{array}{l}-0.0041 \\
(-0.25)\end{array}$ & $\begin{array}{l}0.0094^{\star \star \star} \\
(4.20)\end{array}$ \\
\hline RETURN $_{t-1}$ & $\begin{array}{l}0.8876^{\star \star *} \\
(3.11)\end{array}$ & $\begin{array}{l}0.1323 \\
(1.32)\end{array}$ & $\begin{array}{l}0.4745^{\star \star} \\
(2.41)\end{array}$ & $\begin{array}{l}0.0079 \\
(0.15)\end{array}$ \\
\hline RETURN $_{t-2}$ & $\begin{array}{l}0.0702 \\
(0.20)\end{array}$ & $\begin{array}{l}0.1377 \\
(1.03)\end{array}$ & $\begin{array}{l}-0.2146 \\
(-0.95)\end{array}$ & $\begin{array}{l}0.0632 \\
(1.26)\end{array}$ \\
\hline NUMBER_OF_ARTICLES & $\begin{array}{l}-0.0360^{\star \star \star} \\
(-3.39)\end{array}$ & $\begin{array}{l}-0.0462^{\star \star \star} \\
(-15.69)\end{array}$ & $\begin{array}{l}-0.0348^{\star \star \star} \\
(-3.78)\end{array}$ & $\begin{array}{l}-0.0417^{\text {***}} \\
(-15.77)\end{array}$ \\
\hline ARTICLE_SENTIMENT & $\begin{array}{l}0.4260 \\
(0.69)\end{array}$ & $\begin{array}{l}0.3732^{\star \star \star} \\
(2.85)\end{array}$ & $\begin{array}{l}0.4946 \\
(0.81)\end{array}$ & $\begin{array}{l}0.4315^{\star \star \star} \\
(3.49)\end{array}$ \\
\hline SIZE & & $\begin{array}{l}-0.0773^{\star \star \star} \\
(-4.86)\end{array}$ & & $\begin{array}{l}-0.0778^{\star \star \star} \\
(-4.87)\end{array}$ \\
\hline MARKET-TO-BOOK & & $\begin{array}{l}0.0019 \\
(0.61)\end{array}$ & & $\begin{array}{l}0.0019 \\
(0.62)\end{array}$ \\
\hline BREADTH_OF_OWNERSHIP & & $\begin{array}{l}0.0582 \\
(0.32)\end{array}$ & & $\begin{array}{l}0.0425 \\
(0.23)\end{array}$ \\
\hline NUMBER_OF_ANALYSTS & & $\begin{array}{l}-0.0181 \\
(-1.23)\end{array}$ & & $\begin{array}{l}-0.0189 \\
(-1.29)\end{array}$ \\
\hline ANALYST_DISPERSION & & $\begin{array}{l}-1.4016^{*} \\
(-1.89)\end{array}$ & & $\begin{array}{l}-1.4100^{\star} \\
(-1.88)\end{array}$ \\
\hline INST_OWNERSHIP & & $\begin{array}{l}0.1430^{\star \star} \\
(2.02)\end{array}$ & & $\begin{array}{l}0.1399^{\star \star} \\
(1.97)\end{array}$ \\
\hline $\begin{array}{l}\text { No. of obs. } \\
\text { Adj. } R^{2}\end{array}$ & $\begin{array}{l}4,120 \\
0.36\end{array}$ & $\begin{array}{c}193,664 \\
0.22\end{array}$ & $\begin{array}{l}4,120 \\
0.37\end{array}$ & $\begin{array}{c}193,664 \\
0.28\end{array}$ \\
\hline $\begin{array}{l}\text { Quarterly fixed effects } \\
\text { Daily fixed effects } \\
\text { Firm fixed effects }\end{array}$ & $\begin{array}{l}\text { Yes } \\
\text { No } \\
\text { Yes }\end{array}$ & $\begin{array}{l}\text { Yes } \\
\text { No } \\
\text { Yes }\end{array}$ & $\begin{array}{l}\text { No } \\
\text { Yes } \\
\text { Yes }\end{array}$ & $\begin{array}{l}\text { No } \\
\text { Yes } \\
\text { Yes }\end{array}$ \\
\hline
\end{tabular}

we effectively study the events of additions to and deletions from the S\&P 500 index. Our sample includes 82 instances of such addition/deletion events.

We report our results in Table 10. They show that the effect of information intangibility is smaller for stocks that are members of the S\&P 500 index. The coefficients on the interaction variable are consistently negative and significant across all specifications at $5 \%$ or better. Overall, these findings suggest that liquidity considerations play an important role in causing short sellers to intensify trading on days with qualitative news.

\section{Robustness Checks}

We now consider several robustness checks. One may be concerned that our results are mainly driven by earnings releases, as they are important and usually contain a lot of numerical information. Although this effect would still be in accordance with our hypothesis, it is important to understand whether our results are driven exclusively by the earnings announcements. We therefore reestimate 
TABLE 10

Short Selling as a Function of Information Intangibility:

The Effect of S\&P 500 Addition/Deletion

Table 10 reports the results from daily panel regressions that examine how the relation between information intangibility and short sellers' trading changes after a company is added to/removed from the S\&P 500 index. Dependent variables are REL_SHORT-SALE_TURNOVER, REL_SHORTING, and REL_CLOSING, defined as in Table 2. The explanatory variable of interest is INF_INTANG interacted with an indicator variable that equals 1 when the company is a constituent of the S\&P 500 index (S\&P 500_DUMMY). The control variables are defined as in Table 2. All standard errors are double-clustered at the firm and date levels. The $t$-statistics are reported in parentheses. ${ }^{*},{ }^{* *}$, and ${ }^{* * *}$ indicate significance at the $10 \%, 5 \%$, and $1 \%$ levels, respectively. The sample for this regression consists of news days from July 2006 to Dec. 2008 (excluding the time of the short-sale ban from Sept. 19, 2008 to Oct. 8, 2008).

\begin{tabular}{|c|c|c|c|c|c|c|}
\hline \multirow[b]{3}{*}{ Independent Variables } & \multicolumn{6}{|c|}{ Dependent Variables } \\
\hline & \multicolumn{2}{|c|}{$\begin{array}{c}\text { REL_SHORT-SALE_ } \\
\text { TURNOVER }\end{array}$} & \multicolumn{2}{|c|}{$\begin{array}{c}\text { REL } \\
\text { SHORTING } \\
\end{array}$} & \multicolumn{2}{|c|}{$\begin{array}{l}\text { REL_-_NG } \\
\text { CLOSING }\end{array}$} \\
\hline & 1 & 2 & 3 & 4 & 5 & 6 \\
\hline $\begin{array}{l}\text { INF_INTANG } \times \\
\text { S\&P_500_DUMMY }\end{array}$ & $\begin{array}{l}-0.2391^{\star \star \star} \\
(-2.94)\end{array}$ & $\begin{array}{l}-0.1938^{* *} \\
(-2.49)\end{array}$ & $\begin{array}{l}-0.1256^{\star \star \star} \\
(-2.72)\end{array}$ & $\begin{array}{l}-0.1096^{\star \star} \\
(-2.42)\end{array}$ & $\begin{array}{l}-0.1423^{\star *} \\
(-2.49)\end{array}$ & $\begin{array}{l}-0.1071^{\star \star} \\
(-2.02)\end{array}$ \\
\hline INF_INTANG & $\begin{array}{l}0.2669^{\star \star \star} \\
(4.00)\end{array}$ & 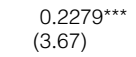 & $\begin{array}{l}0.1089^{* \star *} \\
(2.86)\end{array}$ & $\begin{array}{l}0.0933^{\star \star} \\
(2.54)\end{array}$ & $\begin{array}{l}0.1864^{\text {*** }} \\
(3.78)\end{array}$ & $\begin{array}{l}0.1617^{\text {*ᄎ }} \\
(3.60)\end{array}$ \\
\hline S\&P_500_DUMMY & $\begin{array}{l}-0.0249 \\
(-0.78)\end{array}$ & $\begin{array}{l}-0.0258 \\
(-0.80)\end{array}$ & $\begin{array}{l}-0.0135 \\
(-0.80)\end{array}$ & $\begin{array}{l}-0.0153 \\
(-0.89)\end{array}$ & $\begin{array}{l}-0.0090 \\
(-0.52)\end{array}$ & $\begin{array}{l}-0.0086 \\
(-0.51)\end{array}$ \\
\hline SIZE & $\begin{array}{l}-0.0761^{\text {ᄎ* }} \\
(-4.79)\end{array}$ & $\begin{array}{l}-0.0765^{\text {** }} \\
(-4.79)\end{array}$ & $\begin{array}{l}-0.0360^{* * *} \\
(-4.26)\end{array}$ & $\begin{array}{l}-0.0359^{\star \star \star} \\
(-4.24)\end{array}$ & $\begin{array}{l}-0.0424^{* * *} \\
(-4.32)\end{array}$ & 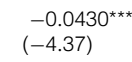 \\
\hline MARKET-TO-BOOK & $\begin{array}{l}0.0017 \\
(0.54)\end{array}$ & $\begin{array}{l}0.0018 \\
(0.55)\end{array}$ & $\begin{array}{l}0.0013 \\
(0.87)\end{array}$ & $\begin{array}{l}0.0013 \\
(0.87)\end{array}$ & $\begin{array}{l}0.0004 \\
(0.18)\end{array}$ & $\begin{array}{l}0.0004 \\
(0.21)\end{array}$ \\
\hline RETURN $_{t-1}$ & $\begin{array}{l}0.1462 \\
(1.48)\end{array}$ & $\begin{array}{l}0.0212 \\
(0.40)\end{array}$ & $\begin{array}{l}0.1962^{\star \star \star} \\
(4.90)\end{array}$ & $\begin{array}{l}0.1773^{\star \star \star} \\
(8.19)\end{array}$ & $\begin{array}{l}-0.0422 \\
(-0.53)\end{array}$ & 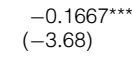 \\
\hline RETURN $_{t-2}$ & $\begin{array}{l}0.1400 \\
(1.06)\end{array}$ & $\begin{array}{l}0.0670 \\
(1.36)\end{array}$ & 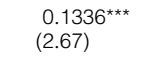 & 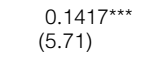 & $\begin{array}{l}0.0250 \\
(0.23)\end{array}$ & $\begin{array}{l}-0.0690 \\
(-1.60)\end{array}$ \\
\hline NUMBER_OF_ARTICLES & $\begin{array}{l}-0.0472^{\star \star \star} \\
(-16.23)\end{array}$ & $\begin{array}{l}-0.0424^{* \star \star} \\
(-16.31)\end{array}$ & $\begin{array}{l}-0.0213^{\star \star \star *} \\
(-13.61)\end{array}$ & 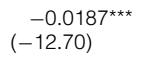 & 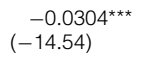 & $\begin{array}{l}-0.0274^{\star \star \star} \\
(-15.13)\end{array}$ \\
\hline ARTICLE_SENTIMENT & $\begin{array}{l}0.3346^{\star \star} \\
(2.52)\end{array}$ & $\begin{array}{l}0.4046^{\star \star \star} \\
(3.27)\end{array}$ & $\begin{array}{l}0.2037^{\star \star *} \\
(2.65)\end{array}$ & $\begin{array}{l}0.2416^{\star \star \star} \\
(3.27)\end{array}$ & $\begin{array}{l}0.2048^{*} \\
(1.93)\end{array}$ & $\begin{array}{l}0.2575^{\star \star \star} \\
(2.59)\end{array}$ \\
\hline BREADTH_OF_OWNERSHIP & $\begin{array}{l}0.1087 \\
(0.59)\end{array}$ & $\begin{array}{l}0.0929 \\
(0.50)\end{array}$ & $\begin{array}{l}-0.0098 \\
(-0.10)\end{array}$ & $\begin{array}{l}-0.0116 \\
(-0.11)\end{array}$ & $\begin{array}{l}0.1391 \\
(1.28)\end{array}$ & $\begin{array}{l}0.1236 \\
(1.12)\end{array}$ \\
\hline NUMBER_OF_ANALYSTS & $\begin{array}{l}-0.0184 \\
(-1.23)\end{array}$ & $\begin{array}{l}-0.0191 \\
(-1.29)\end{array}$ & $\begin{array}{l}-0.0108 \\
(-1.25)\end{array}$ & $\begin{array}{l}-0.0108 \\
(-1.25)\end{array}$ & $\begin{array}{l}-0.0146 \\
(-1.55)\end{array}$ & $\begin{array}{l}-0.0152 \\
(-1.63)\end{array}$ \\
\hline ANALYST_DISPERSION & $\begin{array}{l}-1.3591^{\star} \\
(-1.84)\end{array}$ & $\begin{array}{l}-1.3692^{*} \\
(-1.84)\end{array}$ & $\begin{array}{l}-0.9541^{\text {** }} \\
(-2.51)\end{array}$ & $\begin{array}{l}-0.9622^{\star \star} \\
(-2.52)\end{array}$ & $\begin{array}{l}-0.4869 \\
(-0.99)\end{array}$ & $\begin{array}{l}-0.4795 \\
(-0.97)\end{array}$ \\
\hline INST_OWNERSHIP & $\begin{array}{l}0.1410^{\star \star} \\
(1.99)\end{array}$ & $\begin{array}{l}0.1369^{*} \\
(1.93)\end{array}$ & $\begin{array}{l}0.0426 \\
(1.07)\end{array}$ & $\begin{array}{l}0.0400 \\
(1.00)\end{array}$ & $\begin{array}{l}0.1222^{* * *} \\
(2.75)\end{array}$ & $\begin{array}{l}0.1200^{\star \star \star} \\
(2.69)\end{array}$ \\
\hline $\begin{array}{l}\text { No. of obs. } \\
\text { Adj. } R^{2}\end{array}$ & $\begin{array}{c}196,844 \\
0.22\end{array}$ & $\begin{array}{c}196,844 \\
0.28\end{array}$ & $\begin{array}{c}203,816 \\
0.18\end{array}$ & $\begin{array}{c}203,816 \\
0.21\end{array}$ & $\begin{array}{c}196,844 \\
0.14\end{array}$ & $\begin{array}{c}196,844 \\
0.20\end{array}$ \\
\hline $\begin{array}{l}\text { Quarterly fixed effects } \\
\text { Daily fixed effects } \\
\text { Firm fixed effects }\end{array}$ & $\begin{array}{l}\text { Yes } \\
\text { No } \\
\text { Yes }\end{array}$ & $\begin{array}{l}\text { No } \\
\text { Yes } \\
\text { Yes }\end{array}$ & $\begin{array}{l}\text { Yes } \\
\text { No } \\
\text { Yes }\end{array}$ & $\begin{array}{l}\text { No } \\
\text { Yes } \\
\text { Yes }\end{array}$ & $\begin{array}{l}\text { Yes } \\
\text { No } \\
\text { Yes }\end{array}$ & $\begin{array}{l}\text { No } \\
\text { Yes } \\
\text { Yes }\end{array}$ \\
\hline
\end{tabular}

our four main specifications on the effects of intangible news on short sellers' trading, mean reversion, absolute returns, and Amihud (2002) illiquidity, adding a dummy variable for the week around a firm's quarterly earnings announcement (taken from Computstat). We report the results in Panel A of Table 11. All four tests are robust to controlling for the presence of an earnings announcement, suggesting that our findings are not driven exclusively by such disclosure events.

Next, in Panel B of Table 11, we consider alternative measures of intangibility. We reestimate our four main specifications replacing INF_INTANG with INF_INTANG_DIGIT, which is constructed as the number of digits in the article divided by the number of symbols (instead of the number of numbers divided by the number of words). The results remain significant at the $5 \%$ level. 
In Panel C of Table 11, we reestimate the main specifications of Table 5 using an alternative measure of Amihud (2002) illiquidity based on 5-minute intervals within the day as defined in Section II.C. As before, we observe a significant decrease in illiquidity on intangible news days.

\section{TABLE 11}

\section{Robustness Checks}

Table 11 shows robustness checks for our main analyses. In Panel A, we reestimate our four main regressions adding a dummy variable for the week around a firm's quarterly earnings announcement (EA DUMMY). In Panel B, we reestimate our four main regressions replacing INF_INTANG with the digit-based intangibility measure (INF_INTANG_DIGIT), defined as the number of digits divided by the number of symbols instead of the number of numbers divided by the number of words. In Panel C, we run a robustness check for Table 4, replacing AMIHUD_ILLIQUIDITY with INTRADAY_AMIHUD_ILLIQUIDITY, computed from 5-minute intervals within the day. The control variables are defined as in Table 2. OLS stands for ordinary least squares, FM refers to Fama and MacBeth (1973), and NW refers to Newey and West (1987). The $t$-statistics are reported in parentheses. ${ }^{*},{ }^{* *}$, and ${ }^{* * *}$ indicate significance at the $10 \%, 5 \%$, and $1 \%$ levels, respectively. The sample for all regressions consists of news days from Jan. 1999 to Dec. 2008, except for regression 1 in Panel A and Panel B, where the sample consists of news days from July 2006 to Dec. 2008 (excluding the time of the short-sale ban from Sept. 19, 2008 to Oct. 8, 2008).

Dependent Variables

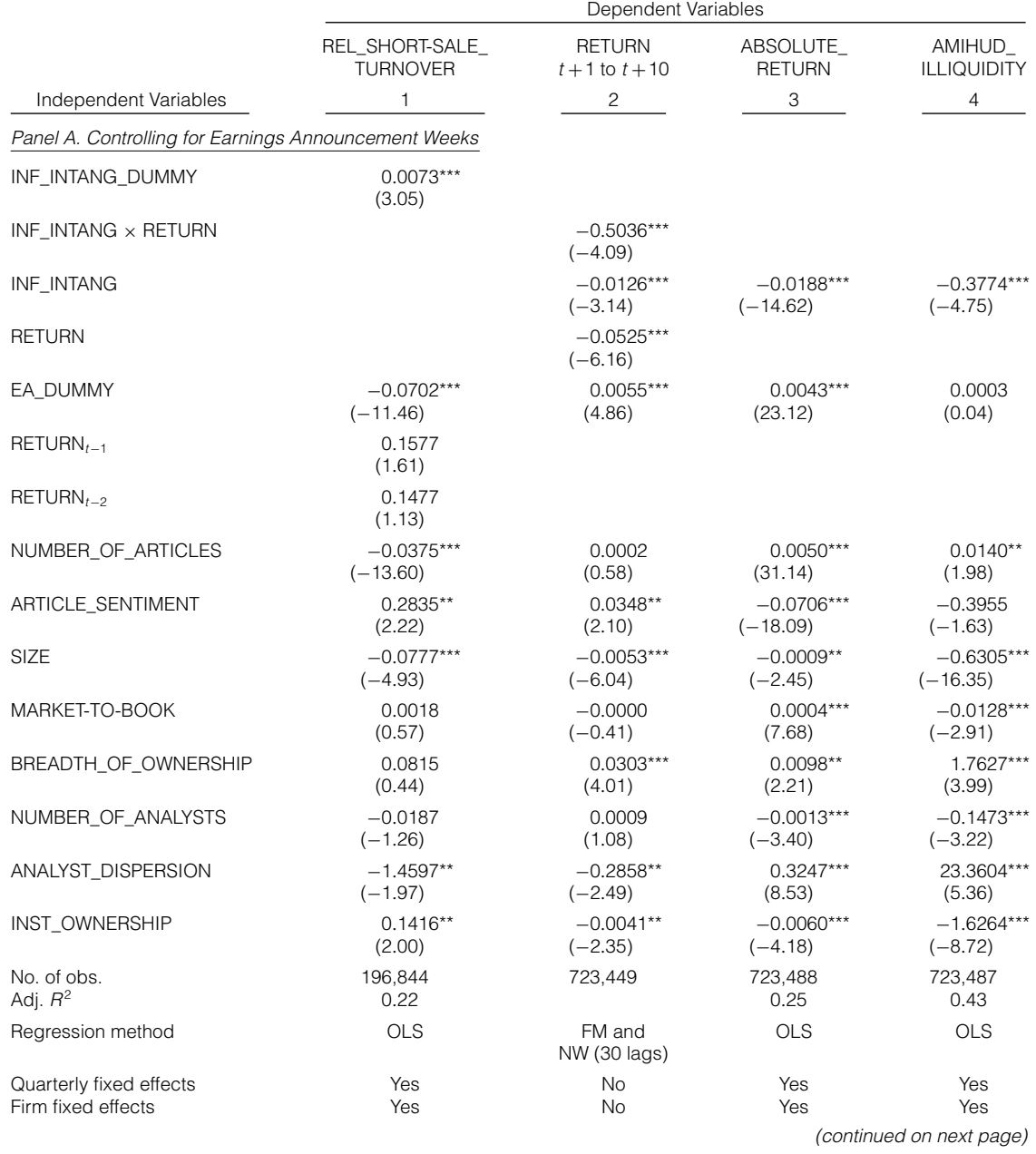


TABLE 11 (continued)

Robustness Checks

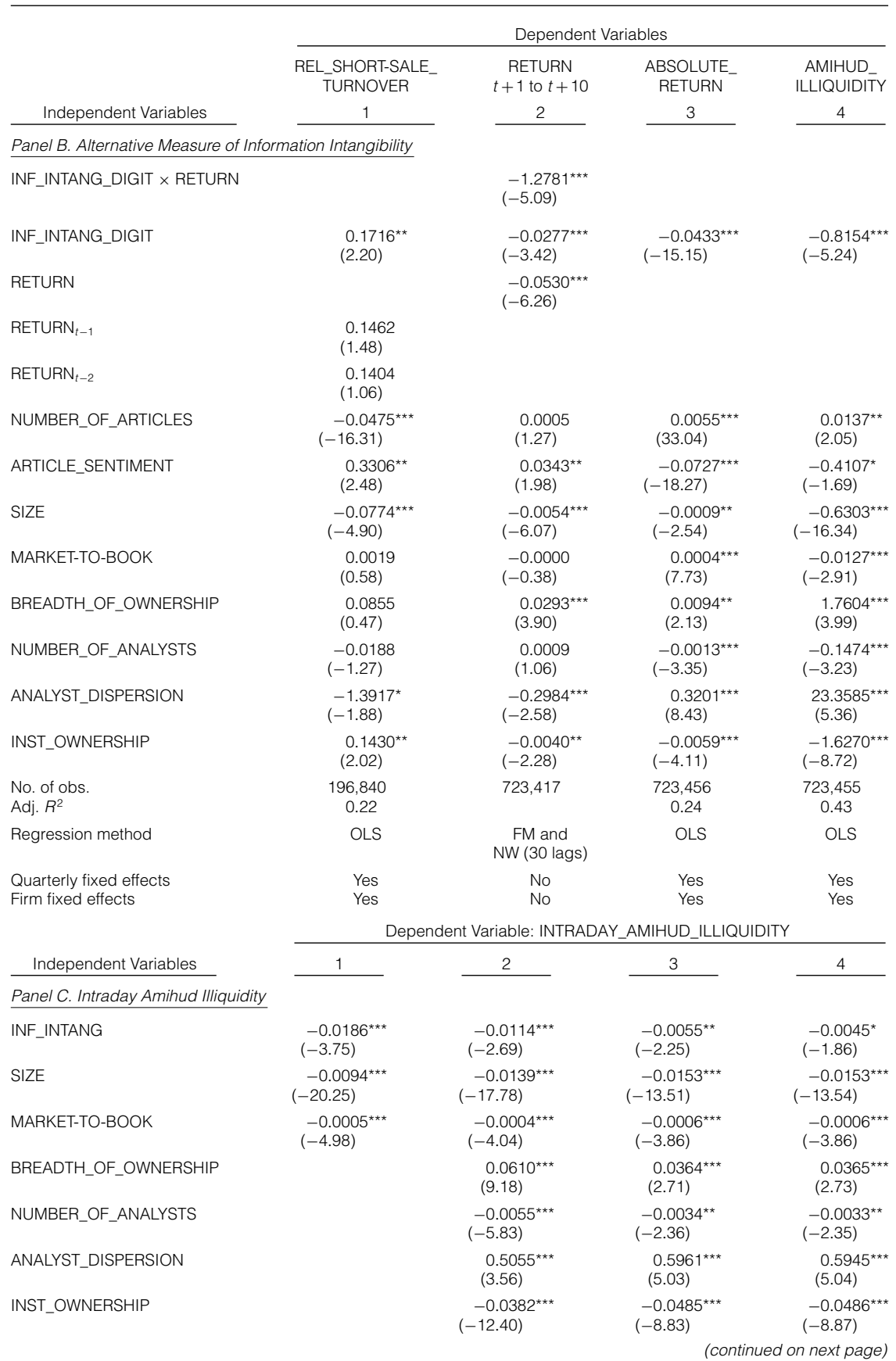




\begin{tabular}{|c|c|c|c|c|}
\hline \multicolumn{5}{|c|}{$\begin{array}{l}\text { TABLE } 11 \text { (continued) } \\
\text { Robustness Checks }\end{array}$} \\
\hline & \multicolumn{4}{|c|}{ Dependent Variable: INTRADAY_AMIHUD_ILLIQUIDITY } \\
\hline Independent Variables & 1 & 2 & 3 & 4 \\
\hline \multicolumn{5}{|c|}{ Panel C. Intraday Amihud Illiquidity (continued) } \\
\hline NUMBER_OF_ARTICLES & & $\begin{array}{l}0.0007^{\star *} \\
(2.20)\end{array}$ & $\begin{array}{l}-0.0003 \\
(-1.22)\end{array}$ & $\begin{array}{l}-0.0001 \\
(-0.64)\end{array}$ \\
\hline ARTICLE_SENTIMENT & & $\begin{array}{l}0.0262^{*} \\
(1.96)\end{array}$ & $\begin{array}{l}0.0115^{\star} \\
(1.66)\end{array}$ & $\begin{array}{l}0.0158^{* \star} \\
(2.29)\end{array}$ \\
\hline $\begin{array}{l}\text { No. of obs. } \\
\text { Adj. } R^{2}\end{array}$ & $\begin{array}{c}789,071 \\
0.28\end{array}$ & $\begin{array}{c}722,646 \\
0.36\end{array}$ & $\begin{array}{c}722,646 \\
0.52\end{array}$ & $\begin{array}{c}722,646 \\
0.53\end{array}$ \\
\hline $\begin{array}{l}\text { Daily fixed effects } \\
\text { Quarterly fixed effects } \\
\text { Firm fixed effects }\end{array}$ & $\begin{array}{l}\text { Yes } \\
\text { No } \\
\text { No }\end{array}$ & $\begin{array}{l}\text { Yes } \\
\text { No } \\
\text { No }\end{array}$ & $\begin{array}{l}\text { No } \\
\text { Yes } \\
\text { Yes }\end{array}$ & $\begin{array}{l}\text { Yes } \\
\text { No } \\
\text { Yes }\end{array}$ \\
\hline
\end{tabular}

\section{Conclusion}

We investigate trading activity of short sellers in both establishing and covering short positions in the presence of noisy trading in the market. We focus on days when qualitative information, measured as the ratio of nonnumerical words to the total number of words in a news article, is released to the market through the media.

We document that short sellers' trading activity increases on these days. We argue that an improvement in liquidity around intangible-news events causes an increase in short sellers' trading. As more noise traders are attracted to the stock, short sellers are able to better disguise their transactions and minimize their impact on the market. In line with this hypothesis, we find that liquidity increases and that returns mean revert more after the release of intangible information. In addition, we find that the relation between information intangibility and short selling is stronger for stocks that are ex ante more illiquid. During the Olympic Games, when potential noise traders' attention is diverted, the effect of intangible information on both liquidity and short selling disappears. Conversely, we do not find evidence that short sellers possess superior ability to interpret intangible news or trade on intangible information contained in the media articles.

Overall, our findings suggest that short sellers exploit noise trading generated by the release of qualitative news to minimize the market impact of their trades. This finding is important as it shows a strategic response of informed investors to exogenous variations in liquidity.

\section{References}

Admati, A., and Paul Pfleiderer. "A Theory of Intraday Patterns: Volume and Price Variability." Review of Financial Studies, 1 (1988), 3-40.

Amihud, Y. "Illiquidity and Stock Returns: Cross-Section and Time-Series Effects." Journal of Financial Markets, 5 (2002), 31-56.

Barber, B., and T. Odean. "All That Glitters: The Effect of Attention and News on the Buying Behavior of Individual and Institutional Investors.” Review of Financial Studies, 21 (2008), 785-818.

Beber, A., and M. Pagano. "Short-Selling Bans around the World: Evidence from the 2007-09 Crisis." Journal of Finance, 68 (2013), 343-381.

Ben-David, I.; F. Franzoni; and R. Moussawi. "Hedge Fund Stock Trading in the Financial Crisis of 2007-2009." Review of Financial Studies, 25 (2012), 1-54. 
Boehmer, E.; C. Jones; and X. Zhang. "Which Shorts Are Informed?” Journal of Finance, 63 (2008), 491-527.

Boehmer, E.; C. Jones; and X. Zhang. "Shackling Short Sellers: The 2008 Shorting Ban.” Review of Financial Studies, 26 (2013), 1363-1400.

Boehmer, E., and J. Wu. "Short Selling and the Price Discovery Process." Review of Financial Studies, 26 (2013), 287-322.

Boudoukh, J.; R. Feldman; S. Kogan; and M. Richardson. "Which News Moves Stock Prices? A Textual Analysis.” Working Paper, New York University (2015).

Bris, A.; W. Goetzmann; and N. Zhu. "Efficiency and the Bear: Short Sales and Markets around the World." Journal of Finance, 62 (2007), 1029-1079.

Bushee, B.; J. Core; W. Guay; and S. Hamm. "The Role of the Business Press as an Information Intermediary." Journal of Accounting Research, 48 (2010), 1-19.

Campbell, J.; S. Grossman; and J. Wang. "Trading Volume and Serial Correlation in Stock Returns." Quarterly Journal of Economics, 108 (1993), 905-939.

Cao, C.; Y. Chen; B. Liang; and A. Lo. "Can Hedge Funds Time Market Liquidity?” Journal of Financial Economics, 109 (2013), 493-516.

Chakravarty, S. "Stealth-Trading: Which Traders' Trades Move Stock Prices?" Journal of Financial Economics, 61 (2001), 289-307.

Chen, J.; H. Hong; and J. Stein. "Breadth of Ownership and Stock Returns." Journal of Financial Economics, 66 (2002), 171-205.

Cohen, L.; K. Diether; and C. Malloy. "Supply and Demand Shifts in the Shorting Market." Journal of Finance, 62 (2007), 2061-2096.

Collin-Dufresne, P., and V. Fos. "Do Prices Reveal the Presence of Informed Trading?" Journal of Finance, 70 (2015), 1555-1582.

Comerton-Forde, C.; C. Jones; and T. Putnins. "Shorting at Close Range: A Tale of Two Types." Journal of Financial Economics, 121 (2016), 546-568.

Diether, K.; K. Lee; and I. Werner. "Short-Sale Strategies and Return Predictability." Review of Financial Studies, 22 (2009), 575-607.

Dougal, C.; J. Engelberg; D. Garcia; and C. Parsons. "Journalists and the Stock Market." Review of Financial Studies, 25 (2012), 439-479.

Eisensee, T., and D. Strömberg. “News Drought, News Floods, and U.S. Disaster Relief.” Quarterly Journal of Economics, 122 (2007), 693-728.

Engelberg, J., and C. Parsons. "The Causal Impact of Media in Financial Markets." Journal of Finance, 66 (2011), 67-97.

Engelberg, J.; A. Reed; and M. Ringgenberg. "How Are Shorts Informed? Short Sellers, News, and Information Processing." Journal of Financial Economics, 105 (2012), 260-278.

Fama, E., and J. MacBeth. "Risk, Return, and Equilibrium: Empirical Tests." Journal of Political Economy, 81 (1973), 607-636.

Fang, L., and J. Peress. "Media Coverage and the Cross-Section of Stock Returns." Journal of Finance, 64 (2009), 2023-2052.

Foster, F., and S. Viswanathan. "A Theory of the Interday Variations in Volume, Variance, and Trading Costs in Securities Markets.” Review of Financial Studies, 3 (1990), 593-624.

Geczy, C.; D. Musto; and A. Reed. "Stocks Are Special Too: An Analysis of the Equity Lending Market.” Journal of Financial Economics, 66 (2002), 241-269.

Griffin, J.; J. Harris; and S. Topaloglu. "The Dynamics of Institutional and Individual Trading." Journal of Finance, 58 (2003), 2285-2320.

Grinblatt, M., and S. Ross. "Market Power in a Securities Market with Endogenous Information." Quarterly Journal of Economics, 100 (1985), 1143-1168.

Hirshleifer, D.; A. Subrahmanyam; and S. Titman. "Security Analysis and Trading Patterns When Some Investors Receive Information before Others.” Journal of Finance, 49 (1994), 1665-1698.

Karpoff, J. “A Theory of Trading Volume.” Journal of Finance, 41 (1986), 1069-1087.

Kyle, A. "Continuous Auctions and Insider Trading." Econometrica, 53 (1985), 1315-1336.

Llorente, G.; R. Michaely; G. Saar; and J. Wang. "Dynamic Volume-Return Relation of Individual Stocks.” Review of Financial Studies, 15 (2002), 1005-1048.

Loughran, T., and B. McDonald. "When Is a Liability Not a Liability? Textual Analysis, Dictionaries, and 10-Ks.” Journal of Finance, 66 (2011), 35-65.

Newey, W., and K. West. "A Simple, Positive Semi-Definite, Heteroskedasticity and Autocorrelation Consistent Covariance Matrix." Econometrica, 55 (1987), 703-708.

Saffi, P., and K. Sigurdsson. "Price Efficiency and Short Selling." Review of Financial Studies, 24 (2011), 821-852.

Stein, J. "Information Production and Capital Allocation: Decentralized versus Hierarchical Firms." Journal of Finance, 57 (2002), 1891-1921. 
Tetlock, P. "Giving Content to Investor Sentiment: The Role of Media in the Stock Market.” Journal of Finance, 62 (2007), 1139-1168.

Tetlock, P. "Does Public Financial News Resolve Asymmetric Information?" Review of Financial Studies, 23 (2010), 3520-3557.

Tetlock, P. "All The News That's Fit to Reprint: Do Investors React to Stale Information?" Review of Financial Studies, 24 (2011), 1481-1512.

Tetlock, P.; M. Saar-Tsechansky; and S. Macskassy. "More Than Words: Quantifying Language to Measure Firms' Fundamentals.” Journal of Finance, 63 (2008), 1437-1467.

Thornock, J. "The Effects of Dividend Taxation on Short Selling and Market Quality." Accounting Review, 88 (2013), 1833-1856.

von Beschwitz, B.; D. Keim; and M. Massa. "Media-Driven High Frequency Trading: Evidence from News Analytics.” Working Paper, INSEAD (2016). 